Sheridan College

SOURCE: Sheridan Institutional Repository

$12-2013$

\title{
Recent Developments and Perspectives on the Treatment of Industrial Wastes by Mineral Carbonation - a Review
}

\author{
Marius Bordor \\ Dunarea de Jos University of Galati \\ Rafael M. Santos \\ Katholieke Universiteit Leuven, rafael.santos@sheridancollege.ca \\ Tom Van Gerven \\ Katholieke Universiteit Leuven \\ Maria Vlad \\ Dunarea de Jos University of Galati
}

Follow this and additional works at: https://source.sheridancollege.ca/fast_chem_publ

Part of the Chemical Engineering Commons

\section{SOURCE Citation}

Bordor, Marius; Santos, Rafael M.; Van Gerven, Tom; and Vlad, Maria, "Recent Developments and Perspectives on the Treatment of Industrial Wastes by Mineral Carbonation - a Review" (2013). Faculty Publications and Scholarship. 15.

https://source.sheridancollege.ca/fast_chem_publ/15

\section{(c) (1) (9)}

This work is licensed under a Creative Commons Attribution-Noncommercial-No Derivative Works 4.0 License. This Article is brought to you for free and open access by the School of Chemical and Environmental Sciences at SOURCE: Sheridan Institutional Repository. It has been accepted for inclusion in Faculty Publications and Scholarship by an authorized administrator of SOURCE: Sheridan Institutional Repository. For more information, please contact source@sheridancollege.ca. 


\title{
Recent developments and perspectives on the treatment of industrial wastes by mineral carbonation - a review*
}

Review article

\author{
Marius Bodor ${ }^{\bullet}$, Rafael M. Santos ${ }^{2 \bullet}$, Tom Van Gerven ${ }^{2}$, Maria Vlad ${ }^{1}$ \\ 1 Department of Environmental Engineering and Metallurgical Technological Systems, "Dunarea de Jos" University of Galati, \\ Galați, Romania \\ 2 Department of Chemical Engineering, KU Leuven, Leuven, Belgium \\ - these co-first authors contributed equally to this work
}

Received 19 March 2013; accepted 29 June 2013

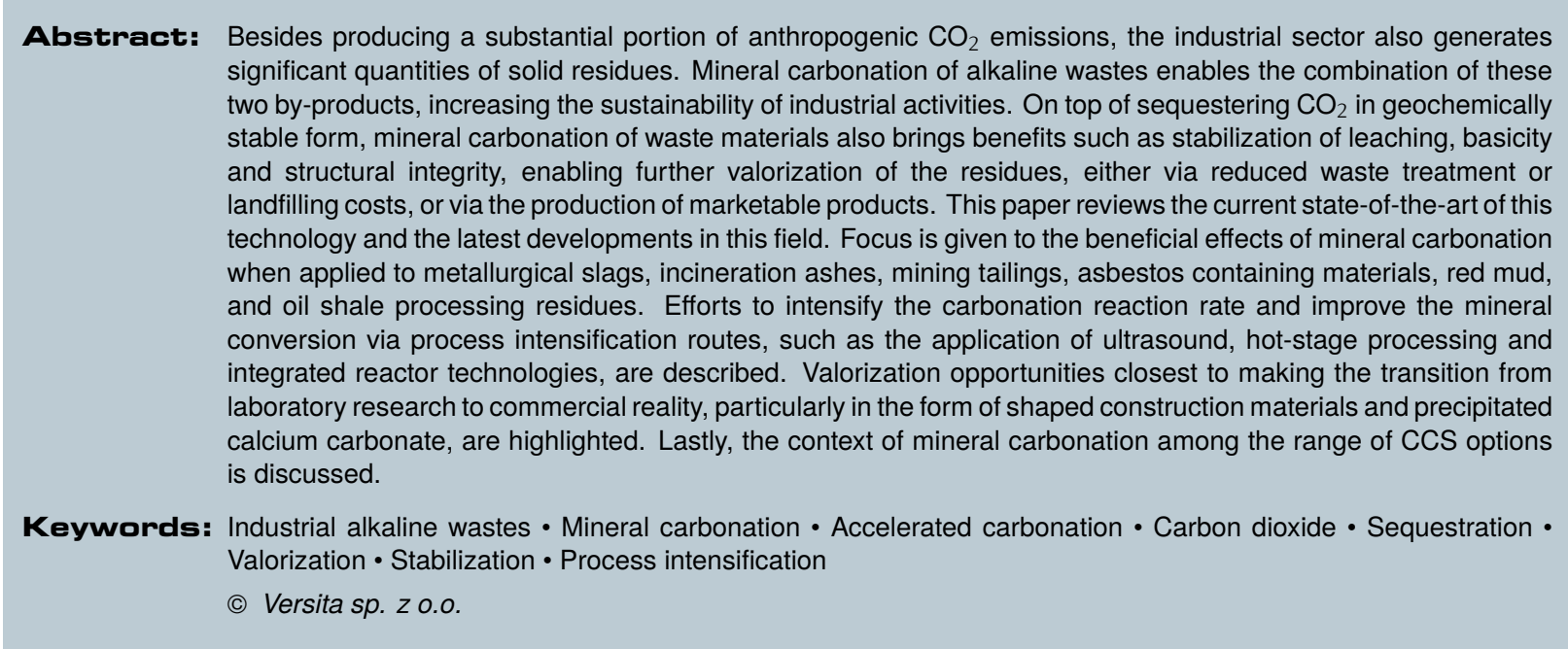

\section{Introduction}

*This paper belongs to the Special Issue devoted to Chemical engineering with focus on environmental and energy resources.

${ }^{\dagger}$ E-mail: Rafael.Santos@alumni.utoronto.ca

Anthropogenic emissions of carbon dioxide $\left(\mathrm{CO}_{2}\right)$, originating mainly from the burning of fossil fuels by the transportation sector and the power generation industry, can be confidently linked, at least in significant part, to the rise in atmospheric levels of carbon dioxide since the 
start of the industrial revolution, from 280 to $390 \mathrm{ppm}$ and climbing [1]. To avoid the potentially detrimental greenhouse gas effects of higher $\mathrm{CO}_{2}$ levels on the climate and life on Earth, the reduction of both the emissions and the atmospheric $\mathrm{CO}_{2}$ levels is essential. However, high availability of fossil fuels and their relatively more affordable market price in contrast with other energy sources represent some of the main reasons for which significant changes in the energetic resources domain has not yet taken place. Furthermore, it has been suggested that the continuation of carbonaceous fuels usage can be extended, beyond the timeline that otherwise would necessitate its phasing out to avoid catastrophic climate change, by the possibility to extract the $\mathrm{CO}_{2}$ directly from atmosphere [2]. While this concept is under promising development [3-5], it is still far from large-scale implementation.

Among the more deployable options for $\mathrm{CO}_{2}$ are an array of technologies that fall under the concept of Carbon Capture and Storage (CCS), which relies on capturing $\mathrm{CO}_{2}$ from concentrated (typically greater than 10-20 vol\%) industrial sources, wherein a purified and pressurized stream of this gas is produced, with the possibility of being easily transported to a storage site. The first method of CCS was that of geological sequestration, which came to be used on a large scale around the 1970s in the extractive industry for enhanced oil and gas recovery [6]. While plenty of capacity may exist for this type of storage [7], there are important concerns over leakage risks and longterm stewardship of the stored $\mathrm{CO}_{2}[8,9]$. An alternative for $\mathrm{CO}_{2}$ sequestration involves $\mathrm{CO}_{2}$ injection in oceans, preferably at great depths where this gas reacts with water to form carbonic acid. However, this method lost its appeal in the last years due to uncertainties regarding environmental impact, particularly that of lowering ocean water $\mathrm{pH}$ and the lack of permanency of this solution [10].

A more attractive option from the point of view of permanent carbon dioxide sequestration is by its trapping as geochemically stable mineral carbonates, a process known as mineral carbonation, mineral sequestration or $\mathrm{CO}_{2}$ mineralization, which was introduced to mainstream science by Seifritz in 1990 [11]. Carbonation of alkaline minerals mimics the natural alteration of calcium- and magnesium-rich rocks as they react with atmospheric $\mathrm{CO}_{2}$ over geological timescales. It is estimated that the natural reserves of calcium and magnesium silicates near the Earth's surface is enough to sequester the $\mathrm{CO}_{2}$ that can be produced from all recoverable fossil fuel reserves [7]. Still, to accelerate the mineral carbonation reaction to meaningful levels, to match the rate of emissions of $\mathrm{CO}_{2}$ from industrial sources, and to achieve carbonation in an economical and net-positive sequestration manner, intensified processing routes are required $[12,13]$.

Besides using widely available natural minerals for carbon sequestration, mineral carbonation can also be applied to a variety of industrial waste materials. These materials are typically by-products of high temperature processes, such as slags and ashes, but can also include tailings from mineral processing operations among other suitable waste materials. These wastes are generally inorganic, alkaline, and possess a high amount of calcium (preferable for its greater reactivity) or possibly magnesium. These materials also have a number of advantages compared to natural minerals: they are generated in industrial areas near large $\mathrm{CO}_{2}$ point sources, have low to negative market price, and have higher reactivity due to their inherent (geo)chemical instability. Additionally, on top of capturing $\mathrm{CO}_{2}$ (i.e. using the waste materials as carbon sinks) other benefits such as stabilization of leaching, basicity and structural integrity enable further valorization of the waste materials, either via reduced waste treatment or landfilling costs, or the production of marketable products. The reduction of industrial waste stockpiling can also result in the liberation of precious land area. A critical mass of research on these topics has formed in recent years by the work of doctoral graduates, the most notable of which include Van Gerven [14], Huijgen [15], Rawlins [16], Teir [17], Uibu [18], Costa [19], Eloneva [20], and Gunning [21], having been reported primarily in the international conferences on Accelerated Carbonation for Environmental and Materials Engineering (ACEME), held in London (2006), Rome (2008), Turku (2010) [22] and Leuven (2013) [23].

Yet, despite the aforementioned benefits and knowledge pool, inefficiencies regarding the high overall cost of the method, uncertainties regarding quality and marketability of valorizable products, the presently low market levels of $\mathrm{CO}_{2}$ capture credits, and the limited $\mathrm{CO}_{2}$ sequestration capacity of these materials (due to small tonnage produced relative to $\mathrm{CO}_{2}$ emission volumes), have delayed the large-scale implementation of mineral carbonation of industrial wastes. This paper reviews the current stateof-the-art of this technology, highlighting successful and promising routes that may eventually transition from the laboratory to the industrial scale.

\section{Mineral carbonation approaches}

Mineral carbonation can be realized using one of the two main directions: direct or indirect carbonation. These methods are represented schematically in Figure 1. 


\section{Direct Carbonation One Step}

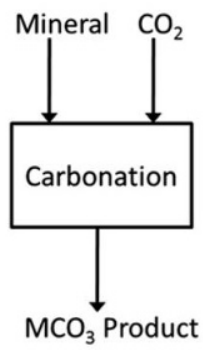

Indirect Carbonation Two or More Steps

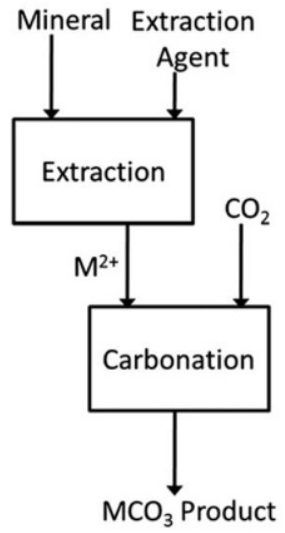

Figure 1. Direct (one step) mineral carbonation (left), and indirect (two or more steps) mineral carbonation (right); $M$ refers to either calcium or magnesium. Reprinted from Progress in Energy and Combustion Science, Vol. 38, Bobicki et al. [24], 302-320, Copyright 2011, with permission from Elsevier.

\subsection{Direct mineral carbonation}

Direct mineral sequestration is the simplest approach regarding mineral sequestration of $\mathrm{CO}_{2}$. Its principle consists in carbonation achievement in a single reaction step, using a dry, moist or aqueous environment [10]. The resulting carbonated material consists of the precipitated carbonate and residual components of the original solid material (e.g. residual silica, iron oxides and unreacted minerals). Typically the basicity of the carbonated material is reduced in the process, becoming buffered by the $\mathrm{pH}$ of the carbonate phases [25-27]. While the technology undoubtedly works, with high degrees of carbonation being achievable in acceptable time periods, traditional processing routes (requiring energy intensive crushing/milling, mixing, pressurization, water treatment, additives use and regeneration, etc.) still prove too expensive for large-scale implementation as a $\mathrm{CO}_{2}$ sequestration solution (e.g. $40-80 € / \mathrm{t} \quad \mathrm{CO}_{2}$ compared with $0.4-6 € / \mathrm{t} \mathrm{CO}_{2}$ for geological sequestration $\left.[28,29]\right)$. But when applied to industrial waste materials, the valorization factor can reduce the gap between cost and benefit.

Promising results using industrial wastes were obtained by Chang et al. [30], using a slurry reactor and converter (BOF) slag with a mean particle size $<44 \mu \mathrm{m}$. The conversion degree was equal to $72 \%$ at $60^{\circ} \mathrm{C}$ and 1 bar (atmospheric) pressure, after 60 minutes. The same group

also investigated the possibility of using residual alkaline water from industrial sources in the carbonation process, with higher $\mathrm{CO}_{2}$ dissolution becoming possible due to the high $\mathrm{pH}$ of the water [31].

Another possibility to improving the carbonation process consists in applying high-power low-frequency (16$100 \mathrm{kHz}$ ) ultrasound. The principle lies in inducing cavitation, that is, the formation of small cavities or micro-bubbles that grow and collapse rapidly. Cavitation generates turbulence/circulation by acoustic streaming, resulting in enhanced mixing and mass transfer, including dissolution of gases such as $\mathrm{CO}_{2}$ [32]. The collapsing micro-bubbles also produce high local temperatures, pressures and shear forces, including the formation of micro-jets. These effects cause solid surface erosion and interparticle collisions, leading to the removal of passivating layers or to the eventual breakage of particles [33]. Santos et al. [26] found that ultrasound increased aqueous (slurry) mineral carbonation rates and conversions when applied to $\mathrm{CaO}$ and stainless steel slags. The enhancement effect was linked to the removal of mass transfer inhibiting passivating layers (precipitated carbonates and residual silica), evidenced by carbonated particle size growth with stirring-only carbonation, and shrinkage when using sonication (Figure 2). However, the energy consumption of the sonication process must be optimized to ensure net $\mathrm{CO}_{2}$ sequestration.

Most carbonation studies to date have aimed to achieve as high as possible $\mathrm{CO}_{2}$ uptake, to maximize the theoretical $\mathrm{CO}_{2}$ sequestration capacity of the materials, determined typically on the basis of the total calcium and magnesium content according to the Steinour equation [34]. Though stoichiometrically accurate, however, this prediction can be overly optimistic, causing doubts whether carbonation processes are ineffective in reaching complete conversion (due to insufficient process severity or formation of passivating layers), or if the unreacted material is inert to carbonation. Doucet [35] studied the solubility of the major silicate and ferrite minerals of BOF slag by acidification, and found that, based on the dissolved amounts of $\mathrm{Ca}$ and $\mathrm{Mg}$ in $0.5 \mathrm{M} \mathrm{HNO}_{3}$, the $\mathrm{CO}_{2}$ uptake of the slag is likely at least $25 \%$ lower than its theoretical capacity. To assess if the carbonation conversion limitations could be attributable to differences in the susceptibility towards mineral carbonation of individual alkaline mineral phases normally found in steel and stainless steel slags, Bodor et al. [27] synthesized and carbonated seven minerals, namely: akermanite $\left(\mathrm{Ca}_{2} \mathrm{MgSi}_{2} \mathrm{O}_{7}\right)$, bredigite $\left(\mathrm{Ca}_{7} \mathrm{Mg}\left(\mathrm{SiO}_{4}\right)_{4}\right)$, cuspidine $\left(\mathrm{Ca}_{4} \mathrm{Si}_{2} \mathrm{O}_{7} \mathrm{~F}_{2}\right), \quad \beta$ - and $\gamma$ dicalcium silicate $\left(\mathrm{Ca}_{2} \mathrm{SiO}_{4}\right)$, merwinite $\left(\mathrm{Ca}_{3} \mathrm{Mg}\left(\mathrm{SiO}_{4}\right)_{2}\right)$, and srebrodolskite $\left(\mathrm{Ca}_{2} \mathrm{Fe}_{2} \mathrm{O}_{5}\right)$. Bredigite was the 


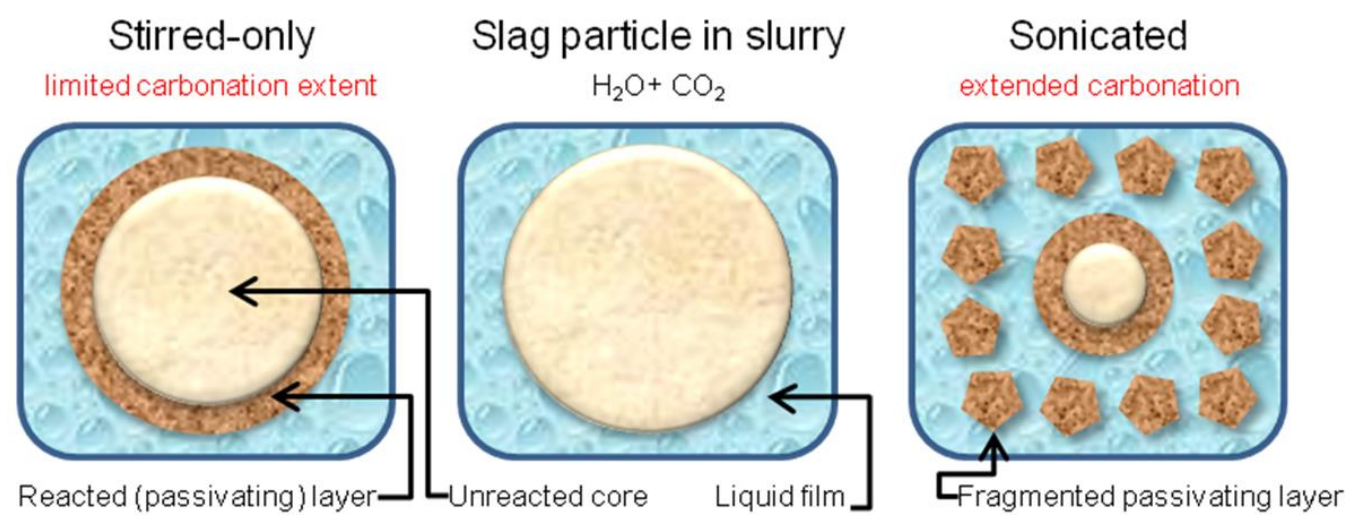

Figure 2. Ultrasound-intensified mineral carbonation. Reprinted from Applied Thermal Engineering, vol. 57, Santos et al. [26], 154-163, Copyright 2012, with permission from Elsevier.

most reactive mineral towards carbonation, though all minerals tested reacted substantially to carbonation, with some variability observed regarding carbonation conversion, carbonation kinetics and utilized carbonation methodology (between the milder moist carbonation and the more intense pressurized slurry autoclave carbonation). These results suggest that mineralogical susceptibility towards mineral carbonation is not the only determining factor controlling carbonation reactivity and $\mathrm{CO}_{2}$ uptake. Particle morphology, in particular grain size and location of the mineral phase components, is equally important, as reactive mineral phases dispersed within less reactive phases do not have the same opportunity to react with $\mathrm{CO}_{2}$ as if they were directly exposed to the reactive medium.

An alternative approach to wet carbonation is hightemperature dry carbonation, which is particularly attractive when the alkaline residues originate from high temperature $\left(>500^{\circ} \mathrm{C}\right)$ processes (e.g. metallurgical slags), where the required thermal energy is intrinsically contained in the system (otherwise, heating cooled products to these temperatures is not a feasible approach) (Figure 3). High temperature carbonation is commonly applied in $\mathrm{CO}_{2}$ capture and separation systems that utilize lime-based sorbents subject to looping carbonation/calcination cycles, which typically conduct carbonation in the flue gas temperature range of $600-700^{\circ} \mathrm{C}$ at atmospheric pressure [36-38]. Prigiobbe et al. [39] tested high temperature carbonation of air pollution control residues in the temperature range of $350-500^{\circ} \mathrm{C}$, obtaining fast carbonation kinetics $(50 \%$ conversion in less than $1 \mathrm{~min}$ ) and high conversions (nearly 80\%). Santos et al. [40] tested three experimental methodologies to study the hot-stage carbonation of converter steel slag: (i) in-situ thermogravimetric analyzer (TGA) carbonation was used to assess carbonation reaction kinetics and thermodynamic equilibrium at high temperatures; (ii) pressurized basket reactor carbonation was used to assess the effects of pressurization, steam addition and slag particle size; and (iii) atmospheric furnace carbonation was used to assess the effect of carbonation on the mineralogy, basicity and heavy metal leaching properties of the slag. Free lime was found to be the primary mineral participating in direct carbonation of slag; silicates were found to be unreactive at these conditions, despite favorable thermodynamics in some cases, probably due to very slow kinetics. Initial carbonation kinetics were comparable at temperatures ranging from 500 to $800^{\circ} \mathrm{C}$, but higher temperatures within this range aided in solid state diffusion of $\mathrm{CO}_{2}$ into the unreacted particle core, thus increasing overall $\mathrm{CO}_{2}$ uptake. The optimum carbonation temperature of both slag and pure $\mathrm{CaO}$ lies just below the transition temperature between carbonation stability and carbonate decomposition: $830-850^{\circ} \mathrm{C}$ and $750-770^{\circ} \mathrm{C}$ at $1 \mathrm{~atm}$ and $0.2 \mathrm{~atm} \mathrm{CO}_{2}$ partial pressures, respectively. Pressurization and steam addition contributed marginally to $\mathrm{CO}_{2}$ uptake, which progressively decreased with increasing particle size, signifying that solid state diffusion controls reaction extent.

\subsection{Indirect mineral carbonation}

The mineral sequestration process divided into several stages is classified as indirect mineral sequestration. $\mathrm{By}$ this method, the reacting alkaline element ( $\mathrm{Ca}, \mathrm{Mg}$, or both) is first extracted from the feedstock, and in a separate stage will react with $\mathrm{CO}_{2}$ to form carbonates, 


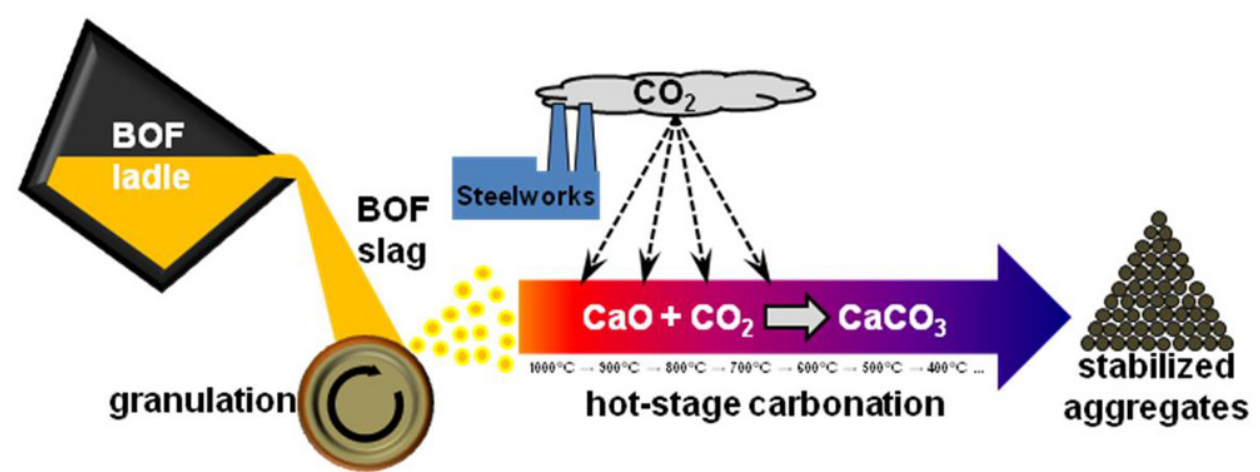

Figure 3. Stabilization of basic oxygen furnace slag by hot-stage carbonation treatment. Reprinted from Chemical Engineering Journal, Vol. 203, Santos et al. [40], 239-250, Copyright 2012, with permission from Elsevier.

according to Eq. (1) and (2), where wollastonite $\left(\mathrm{CaSiO}_{3}\right)$ and acetic acid $\left(\mathrm{CH}_{3} \mathrm{COOH}\right)$ are used as example [17]:

$\mathrm{CaSiO}_{3}+2 \mathrm{CH}_{3} \mathrm{COOH} \rightarrow \mathrm{Ca}^{2+}+2 \mathrm{CH}_{3} \mathrm{COO}^{-}+\mathrm{H}_{2} \mathrm{O}+\mathrm{SiO}_{2}$

$\mathrm{Ca}^{2+}+2 \mathrm{CH}_{3} \mathrm{COO}^{-}+\mathrm{CO}_{2}+\mathrm{H}_{2} \mathrm{O} \rightarrow \mathrm{CaCO}_{3}+2 \mathrm{CH}_{3} \mathrm{COOH}$

When the product formed is calcium carbonate, it is commonly referred to as precipitated calcium carbonate (PCC), a product that has diverse industrial applications, such as in papermaking, polymers, paint and fertilizer. An attractive feature of indirect mineral carbonation, besides the production of relatively pure carbonate products with potentially high market value, is that a major limitation of direct carbonation for achieving high conversion rates and $\mathrm{CO}_{2}$ uptake, namely the mobility of the alkaline elements from the solids, can be more easily overcome by the use of strong acids, and also by the inherent elimination of the carbonate passivating layer that blocks access to the unreacted particle core.

As such, much research on identifying and testing suitable leaching agents, which ideally should have high extraction efficiency, but at the same time should have less affinity for the alkaline-earth elements than the carbonate ion $\left(\mathrm{CO}_{3}^{2-}\right)$ to allow for the precipitation of carbonates in the secondstage carbonation step. For instance, Bonfils et al. [41] used disodium oxalate $\left(\mathrm{Na}_{2}\left(\mathrm{C}_{2} \mathrm{O}_{4}\right)\right)$ for the extraction of magnesium from serpentine, but found that carbonation of the leachate resulted in the precipitation of magnesium oxalate dihydrate $\left(\mathrm{Mg}\left(\mathrm{C}_{2} \mathrm{O}_{4}\right) \cdot 2 \mathrm{H}_{2} \mathrm{O}\right)$, an organic acid salt, instead of the desired magnesium carbonate. Similarly, Chiang et al. [42] report that the carbonation precipitate from succinic acid leachate derived from blast furnace steel slag is calcium succinate $\left(\mathrm{Ca}\left(\mathrm{C}_{4} \mathrm{H}_{4} \mathrm{O}_{4}\right)\right)$ rather than calcium carbonate.
Acetic acid $\left(\mathrm{CH}_{3} \mathrm{COOH}\right)$ has been successfully applied for the production of PCC from steel slag [43], but after extraction it is necessary to add sodium hydroxide to neutralize the acid and promote carbonate precipitation; the formed sodium acetate can potentially be regenerated into acetic acid, but at a large processing cost. To avoid regeneration, Eloneva et al. [44] also tested the efficacy of ammonium salts $\left(\mathrm{NH}_{4} \mathrm{Cl}, \mathrm{CH}_{3} \mathrm{COONH}_{4}, \mathrm{NH}_{4} \mathrm{NO}_{3}\right)$ and found positive results with steel converter slag, but the efficiency was poorer for blast furnace and ladle slags; this was attributed to calcium being predominantly bound as silicates in these materials (as opposed to free lime $(\mathrm{CaO})$ in converter slag). The loss of ammonia $\left(\mathrm{NH}_{3}\right)$ in the off-gas also becomes an added concern when using these additives [45].

This is by no means an exhaustive review of recent works on indirect carbonation, but a general trend observed from this field of study is that, while a valuable product can be produced from waste materials, other troublesome products are also formed, including destabilized heavymetal containing residual solids, and salt and heavy metal laden wastewater. As such, the objective of waste treatment is not fully realized. In view of overcoming this deficiency, Chiang et al. [42] investigated the potential of two-way valorization of blast furnace slag via: 1) production of PCC from the initial-stage extraction step; and 2) utilization of the solid residue for the production of microporous and mesoporous materials that have the potential to be applied as sorbents, and that at the same time can act to stabilize the intrinsically contained hazardous components. In this study, hydrothermal conversion of the residual solids from the extraction stage in strongly alkaline solution (with $\mathrm{NaOH}$ addition) resulted in the formation of zeolitic phases having reported capacity for heavy metal adsorption. This 
route proves particularly attractive as the benefits of mineral carbonation and waste stabilization/valorization are symbiotically combined.

\section{Treatment of industrial alkaline wastes by mineral carbonation}

There are numerous sources of industrial wastes that can be used in the mineral carbonation processes, with varying chemical, mineralogical and morphological properties, and available in small to large quantities and in limited to wide geographical distribution. Significant amount of technological progress is still needed until widespread adoption of mineral carbonation on an industrial scale, but the body of research has already reached a level that guarantees sustained development for years to come. At this moment, the scientific literature contains an assortment of satisfactory, though preliminary, results, the most recent and relevant of which are reviewed in this section, organized by class of waste material: metallurgical slags, incineration ashes, mining tailings, asbestos containing materials, red mud, and oil shale processing residues.

\subsection{Metallurgical slags}

Steel slags, by-products of steel production processes, are a widely available class of industrial waste materials that can potentially benefit from mineral carbonation through the reduction in basicity $(\mathrm{pH})$, swelling stabilization, and reduction of heavy metals leaching $[25,26,40,46]$. Currently, the treatment and disposal of these slags presents a costly burden on steel plants. Moreover, their high $\mathrm{CO}_{2}$ uptake capacities, coupled to the large onsite $\mathrm{CO}_{2}$ emissions of steelworks, offers opportunities for carbon capture credit gains.

\subsubsection{Carbon steel slags}

Integrated carbon steel production consists of ironmaking in the Blast Furnace (BF), steelmaking in the Basic Oxygen Furnace (BOF), and continuous casting of steel billets, slabs and blooms. For over a century, with iron and steel industry booming worldwide, a vast amount of slag has been produced as an inevitable by-product of the steelmaking process. While valuable applications have been found for BF slag, mostly in the construction sector such as in cement manufacturing and as a cement replacement in concrete, much of BOF slag production, estimated at $60-120 \mathrm{~kg} / \mathrm{t}$ steel presently, still ends up in landfill sites $[47,48]$. The traditional use of BOF slag in road construction, as an aggregate, base or sub-base
Table 1. Example of BOF slag chemical composition, expressed as oxides [52].

\begin{tabular}{ll}
\hline Oxide & Amount (wt\%) \\
\hline $\mathrm{CaO}$ & 47.7 \\
$\mathrm{Fe}_{2} \mathrm{O}_{3}$ & 24.4 \\
$\mathrm{SiO}_{2}$ & 13.3 \\
$\mathrm{MgO}$ & 6.4 \\
$\mathrm{Al}_{2} \mathrm{O}_{3}$ & 3.0 \\
$\mathrm{MnO}$ & 2.6 \\
$\mathrm{P}_{2} \mathrm{O}_{5}$ & 1.5 \\
$\mathrm{TiO}_{2}$ & 0.7 \\
\hline
\end{tabular}

coarse, has been restricted due to the slag's undesirable expansive nature, resulting in rapid deterioration of the roads [49]. The volume expansion (up to 10\% [50]) is attributed to the short term hydration and the long term carbonation of free lime $(\mathrm{CaO})$ and magnesium oxide $(\mathrm{MgO})$ content [51], present in significant amounts due to the high $(\mathrm{CaO}+\mathrm{MgO}): \mathrm{SiO}_{2}$ ratio of the slag (Table 1). Compared to present BOF slag treatment processes, applied in limited extent due to high processing costs and variable performance [40], the reaction of the alkaline oxides with $\mathrm{CO}_{2}$, leading to the formation of geochemically stable carbonates (e.g. $\mathrm{CaCO}_{3}$ ), is a potentially sustainable route. Besides capture of $\mathrm{CO}_{2}$, desirable for emissions reduction, mineral carbonation also yields positive effects in terms of the leaching behavior of alkaline earth metals, heavy metals and metalloids from steel slag [46], which can lead to further valorization of the waste material. Numerous studies in recent years have assessed the potential of steel slag carbonation for storage of $\mathrm{CO}_{2}$ utilizing a variety of direct carbonation routes, including slurry carbonation [30, 31, 53, 54], wet carbonation [55], block carbonation [56], and hot-stage carbonation $[40,57]$.

Huijgen et al. [53] systematically studied the effect of process variables including particle size, temperature, $\mathrm{CO}_{2}$ partial pressure, and reaction time on the slurry carbonation extent of milled BOF slag in a stirred batch autoclave reactor. The optimal condition was found to be 30 minutes at 19 bar $\mathrm{CO}_{2}, 100^{\circ} \mathrm{C}$, and a particle size of $<38 \mu \mathrm{m}$, with which $74 \%$ Ca-conversion was achieved. The most influential process parameters were found to be particle size (varied from $<2 \mathrm{~mm}$ to $<38 \mu \mathrm{m}$ ) and reaction temperature (varied from 25 to $225^{\circ} \mathrm{C}$ ).

Van Zomeren et al. [55] investigated accelerated BOF slag carbonation at relatively low $\mathrm{CO}_{2}$ pressure $(0.2$ bar), in view of improving the environmental properties of slag ( $\mathrm{pH}$ and leaching). Gas-solid experiments were performed in laboratory columns under water-saturated and unsaturated conditions (i.e. moist and dry gas), and temperatures between 5 and $90^{\circ} \mathrm{C}$. The major changes 
in the amount of sequestered $\mathrm{CO}_{2}$ and the resulting $\mathrm{pH}$ reduction ( 1.5 units) occurred within 24 hours, and were proportional to the free lime content of the slag, suggesting little reactivity of other mineral phases at these conditions. Also, carbonation at these conditions was found to occur predominantly at the surface of the slag grains (sieved to $2-3.3 \mathrm{~mm}$ in size). However, the $\mathrm{pH}$ reduction after carbonation led to increased vanadium leaching.

In order to eliminate several disadvantages of conventional mineral carbonation processes, Santos et al. [40] proposed studying the carbonation of BOF slag during cooling from the high temperature molten slag source. In this respect, carbonation during granulation was suggested (Figure 3). Experiments showed the optimal carbonation temperature to be situated under the transition temperature from carbonation stability to decomposition $\left(830-850^{\circ} \mathrm{C}\right.$, at atmospheric pressure) and to be rapid (order of a few minutes). Improvement regarding the basicity was found to be independent of particle size, though $\mathrm{CO}_{2}$ uptake significantly reduced with larger particles (varied from $<0.08$ to $<1.6 \mathrm{~mm}$ ), and hence smaller specific surface area. The solubility of some heavy metals reduced after carbonation ( $\mathrm{Ba}, \mathrm{Co}$ and $\mathrm{Ni}$ ), but $\mathrm{Cr}$ and $\mathrm{Mo}$ leaching moderately increased, and that of $\mathrm{V}$ increased significantly. The authors suggest that the increased solubility of vanadium (and to a smaller extent chromium) after carbonation can be used as a means to ease their recovery from the residues, as these metals can be of commercial value. Alternatively, if the carbonated BOF slag is used as a fine aggregate in cement mortar/concrete, the cementitious matrix itself can act as a sink for heavy metals, by incorporation of metalloids in hydration products [58], thereby suppressing leaching.

\subsubsection{Stainless steel slags}

To date, most research on single-step aqueous carbonation of steel slags have focused on Basic Oxygen Furnace (BOF) slag, and on Electric Arc Furnace (EAF) slag, originating from the first step of the stainless steel production and with results recently reported by Baciocchi et al. $[25,59]$. However, a main disadvantage to the carbonation of these residues is the milling requirement to generate sufficient reactive surface area, as these slags solidify upon cooling in the form of monoliths. Two additional slags produced from the stainless steel process possess powdery morphology and can benefit in a more energy efficient manner from mineral carbonation: Argon Oxygen Decarburization (AOD) slag, and Continuous Casting (CC) slag, also referred to as Ladle Metallurgy (LM) slag. Typical chemical composition of AOD slag is presented in Table 2.
Table 2. Typical chemical composition of AOD slag, expressed as oxides [60].

\begin{tabular}{ll}
\hline Oxide & Amount (wt\%) \\
\hline $\mathrm{CaO}$ & $46-54$ \\
$\mathrm{SiO}_{2}$ & $26-31$ \\
$\mathrm{Al}_{2} \mathrm{O}_{3}$ & $2-10$ \\
$\mathrm{MgO}$ & $4-7$ \\
$\mathrm{MnO}$ & $1-2$ \\
$\mathrm{Fe}$ & $1-2$ \\
$\mathrm{Cr}$ & $2-4$ \\
\hline
\end{tabular}

AOD slag exhibits a peculiar disintegration upon cooling due to the phase transformation of $\beta$-dicalcium silicate to the more stable, but less dense, $\gamma$-dicalcium silicate, causing detrimental expansion forces in the material [61]. The slag turns into a fine powder that causes severe dust issues during handling and storage in the steelworks; furthermore, the slag in this form cannot be readily reutilized or valorized, and often must be landfilled [62]. Concerns regarding drainage from steel slag disposal sites, which can be extremely alkaline and a source of pollution to surface and ground waters [63], add to the disposal costs. Treatment strategies including the addition of stabilizing ions (e.g. boron), silica and rapid cooling, which aim at preventing the disintegration of the slags by hindering the expansive $\beta$ - to $\gamma$ - transformation of dicalcium silicate $\left(\mathrm{Ca}_{2} \mathrm{SiO}_{4}\right)$, have been tested and, in some cases, implemented in industry [64]. However, costly and energy intensive processes, hazardous additives that introduces environmental concerns regarding leaching, and low-value final products still force the industry to search for more sustainable solutions. Furthermore, this methodology is not applied to CC slag due to process complexities, and the slag is disposed of in powdery form by landfilling. For mineral carbonation processes however, this behavior represents an advantage, as the reactive surface area is maximized; as such, some researchers have taken advantage of this to accelerate the carbonation rate and reduce processing energy expenditure.

Baciocchi et al. [25] studied the wet carbonation route with boron-free AOD slag (powder), and found maximum $\mathrm{CO}_{2}$ uptake after 8 hours at $50^{\circ} \mathrm{C}, 10$ bar $\mathrm{CO}_{2}$ and 0.4 liquid-to-solid (L/S) ratio. The $\mathrm{CO}_{2}$ uptake of the aged slag, determined by calcimetry, was about $30 \mathrm{wt} \%$, equivalent to $70 \%$ Ca-conversion yield. The leaching behavior of the carbonated slag was also modified, exhibiting a reduction by 2 units from the original $\mathrm{pH}$ of the slag, accompanied by a decrease of Ca release and an increase of $\mathrm{Si}$ leaching, as a result of modified leaching-controlling phases. Vandevelde [65] studied both boron-free AOD and CC slags (fresh powders) in wet carbonation at very mild conditions. Comparison of 
carbonation at $30^{\circ} \mathrm{C}$ and $50^{\circ} \mathrm{C}, 0.1$ and 0.2 atm. $\mathrm{CO}_{2}$, and $\mathrm{L} / \mathrm{S}$ varying from 0 to 0.5 , allowed for determination of the optimum process conditions: $30^{\circ} \mathrm{C}, 0.2 \mathrm{~atm} . \mathrm{CO}_{2}$, $\mathrm{L} / \mathrm{S}=0.3$. At these conditions, over 6 days, the $\mathrm{CO}_{2}$ uptake of AOD and CC slags were 11 and $15 \mathrm{wt} \%$ respectively, equivalent to $32 \%$ and $45 \%$ Ca-conversion, respectively. Santos et al. [66] accelerated the process by performing slurry carbonation in a stirred autoclave. Over 6 hours, at $60^{\circ} \mathrm{C}$ and 3 bar $\mathrm{CO}_{2}$, fresh $\mathrm{AOD}$ slag reached $12 \mathrm{wt} \% \mathrm{CO}_{2}$ uptake (37\% Ca-conversion) and fresh CC slag attained $17 \mathrm{wt} \% \mathrm{CO}_{2}$ (52\% Ca-conversion). An attempt to realize $A O D$ slag carbonation using higher temperatures and pressures was done by Van Bouwel [67]. Process temperature used in experiments varied between 30 and $180^{\circ} \mathrm{C}$, the $\mathrm{CO}_{2}$ partial pressure between 2 and 30 bar, and the reaction time between 1 minute and 2 hours, with continuous agitation (1000 rpm). Best results were obtained at $90^{\circ} \mathrm{C}, 30$ bar $\mathrm{CO}_{2}$, after one hour and with an $\mathrm{L} / \mathrm{S}$ ratio equal to 16 . Using these conditions, $63 \%$ Ca-conversion of AOD slag was realized, the $\mathrm{pH}$ dropped from 11.7 to 9.4 , and leaching of heavy metals decreased (except for V).

Santos et al. [68] report accelerated carbonation results undertaken on both AOD and CC slags, using two methodologies: unpressurized moist (thin-film) carbonation, and pressurized slurry carbonation. The influence of process parameters (temperature, $\mathrm{CO}_{2}$ partial pressure, time, liquid-to-solid ratio) on the slag carbonation kinetics was investigated, seeking the optimal conditions that maximize the potential of the slags as carbon sinks. It was found that CC slag carbonates more extensively than AOD slag due to differences in particle microstructure; maximum $\mathrm{CO}_{2}$ uptakes reached 24 and $21 \mathrm{wt}^{\%} \mathrm{CO}_{2}$, for each respective slag, at optimal processing conditions via pressurized slurry carbonation. Mineral carbonation conversion was accompanied by significant reduction in basicity, as much as two $\mathrm{pH}$ units, and stabilization of heavy metals leaching, meeting regulatory limits for safe waste materials re-use. While slurry carbonation was found to deliver greater mineral carbonation conversion and optimal treatment homogeneity, required for commercial valorization, thinfilm carbonation may be a more feasible route for the utilization of slags solely as carbon sinks, due to the elimination of several processing steps and reduction of energy demand.

\subsection{Incineration ashes}

Municipal solid waste incineration (MSWI) is a waste management technology that is predominantly utilized in geopolitical regions where land availability is scarce, thereby limiting landfilling capacity, and where strict environmental regulations or tax incentives encourage incineration. The generation of energy from the combustion of the waste, termed waste-to-energy (WtE), is an additional benefit of this technology. Although incineration enables reduction in waste volume by up to 90 vol\% [69], substantial amounts of residues are produced, including fly ashes and even greater amounts of bottom ashes (BA), which can reach $20-30 \mathrm{wt} \%$ of the original waste mass [70]. These solid residues are the final sinks for salts and numerous toxic and regulated heavy metals and metalloids, which severely limit the possibilities for valorization of these materials.

In lack of suitable valorization routes for MSWI-BA, the common industrial practice to date has been natural ageing of the material, with the aim of promoting weathering and thus reducing leaching to environmentally acceptable levels, prior to final disposal and storage in landfills. In order to accelerate and enhance the ageing mechanisms, and thus permit further valorization of the ashes, accelerated carbonation has been identified as a potential route (previously reviewed by Costa et al. [71]). Notable studies on accelerated carbonation of MSWI-BA include those of Van Gerven et al. [70], Arickx et al. [69], Rendek et al. [72] and Baciocchi et al. [73]. The common process methodology has been moist carbonation, whereby the solids are mixed with a limited amount of water (0.2-0.3 liquid-to-solid ratio (L/S) has been found ideal) and exposed to a $\mathrm{CO}_{2}$-rich atmosphere (10-100 vol\% $\left.\mathrm{CO}_{2}\right)$ at moderate temperatures $\left(30-50^{\circ} \mathrm{C}\right)$ for several hours to several days (up to 7 days being common) in static condition (e.g. thinly spread layers). The general precept is to maintain the temperature low enough to maximize $\mathrm{CO}_{2}$ solubility in the water phase, but high enough to drive the carbonation reaction kinetics. Moreover, it is desirable to use a moisture content in the mixture that provides the water required for aqueous carbonation reaction (i.e. dissolved carbonates reacting with calcium and magnesium, leached from hydrated oxides and silicates, at the reacting zone near the particle surface), but that is thin enough to limit the diffusion distance the carbonate ion has to travel to reach the reaction zone (i.e. thin-film instead of flooded sample). Rendek et al. [74] found that pressurization of the gas aids carbonation kinetics reducing time to reaction completion from 51 to 3.5 hours, but not having a significant effect on carbonation conversion $/ \mathrm{CO}_{2}$ uptake. The aforecited studies report improvement in the leaching behavior of certain metals, especially $\mathrm{Cu}, \mathrm{Pb}$ and $\mathrm{Zn}$, but detrimental effect on the leaching of $\mathrm{Cr}$, Mo and Sb.

Um et al. [75] subjected municipal solid waste incinerator bottom ash (MSWI-BA) with particle size $<150 \mu \mathrm{m}$ 
to carbonation using 30 vol\% $\mathrm{CO}_{2}$ with $0.3 \mathrm{~L} / \mathrm{S}$ at different temperatures $\left(20-40^{\circ} \mathrm{C}\right)$, for the purpose of studying the leaching behavior of $\mathrm{Cr}$. XRD results showed that portlandite $\left(\mathrm{Ca}(\mathrm{OH})_{2}\right)$, ettringite $\left(\mathrm{Ca}_{6} \mathrm{Al}_{2}\left(\mathrm{SO}_{4}\right)_{3}(\mathrm{OH})_{12} \cdot 26 \mathrm{H}_{2} \mathrm{O}\right)$ and hydrocalumite $\left(\mathrm{Ca}_{8} \mathrm{Al}_{4}(\mathrm{OH})_{12}\left(\mathrm{Cl}, \mathrm{CO}_{3}, \mathrm{OH}\right)_{2-x} \cdot 4 \mathrm{H}_{2} \mathrm{O}\right)$ disappeared from the material's composition after carbonation experiments. The $\mathrm{pH}$ decreased from almost 12 to almost 9 after 4 hours of carbonation. Leaching of $\mathrm{Cr}$ registered an increase in the first minutes of the carbonation experiment (due to decomposition of ettringite and hydrocalumite) followed by a continuous decrease after 30 minutes (due to formation of insoluble $\mathrm{Cr}$-material and the adsorption effect of amorphous Al-materials having high affinity for $\mathrm{Cr}$ ).

Santos et al. [76] compared the performance of four different approaches for stabilization of regulated heavy metal and metalloid leaching from household and light industrial solid waste incineration bottom ashes (MSWIBA): (i) short term (three months) heap ageing, (ii) heat treatment, (iii) accelerated moist carbonation, and (iv) accelerated pressurized slurry carbonation. The leaching values of all samples were compared to Flemish (NEN 7343) and Walloon (DIN 38414) regulations from Belgium. Batch leaching of the fresh ashes at natural $\mathrm{pH}$ showed that seven elements exceeded at least one regulatory limit $(\mathrm{Ba}, \mathrm{Cr}, \mathrm{Cu}, \mathrm{Mo}, \mathrm{Pb}, \mathrm{Se}$ and $\mathrm{Zn})$, and had excess basicity $(\mathrm{pH}>12)$. Accelerated carbonation achieved significant reduction in ash basicity (9.3-9.9); lower than ageing (10.5-12.2) and heat treatment (11.112.1). Slurry carbonation was deemed the most effective treatment process, achieving consistently significant leaching stabilization, while also effectively washing out $\mathrm{Cl}$ ions, a requirement for the utilization of the ashes in construction applications. The benefits of carbonation were linked to the formation of significant quantities of Ca-carbonates, including appreciable quantities of the aragonite $\mathrm{CaCO}_{3}$ polymorph formed in the slurry carbonated samples.

\subsection{Mining tailings and asbestos containing materials}

An attractive route to efficient above-ground carbon capture and storage (CCS) is the utilization of already mined and milled tailings residues, which possess high surface area and porosity, for mineral carbonation. Their large-scale availability stoichiometrically places them among the few realistic options for buffering the $\mathrm{CO}_{2}$ emissions of today's fossil-fuel driven economy. Especially suitable are ultramafic wastes due to their high content of $\mathrm{Mg}$-rich minerals (e.g. olivine $\left((\mathrm{Mg}, \mathrm{Fe})_{2} \mathrm{SiO}_{4}\right)$ and serpentine $\left.\left((\mathrm{Mg}, \mathrm{Fe})_{3} \mathrm{Si}_{2} \mathrm{O}_{5}(\mathrm{OH})_{4}\right)\right)$. However, these wastes can also contain abundant quantities of the hazardous asbestiform (fibrous) polymorphs, such as chrysotile $\left(\mathrm{Mg}_{3}\left(\mathrm{Si}_{2} \mathrm{O}_{5}\right)(\mathrm{OH})_{4}\right)$. For example, historical mining activities in the towns of Thetford Mines and Asbestos (Québec, Canada) have led to the accumulation of approximately 2 billion tonnes of chrysotile-rich wastes [77].

Assima et al. [78] studied the sensitivity to seasonal temperature variations $\left(10\right.$ to $\left.40^{\circ} \mathrm{C}\right)$ of mineral carbonation of a saturated nickel mine residue under humid environments. The authors suggest the possibility of heat recovery by low-temperature geothermal systems, as a $4.9^{\circ} \mathrm{C}$ increase in temperature is registered even for experiments at $10^{\circ} \mathrm{C}$. In addition to $\mathrm{CO}_{2}$ capture, the asbestiform nature of the mineral can be destroyed upon carbonation [79], rendering the process also a remediation solution. This approach also has the potential to be used for treatment of asbestos wastes from the construction industry (e.g. demolition and renovation), such as cementasbestos, as an alternative to costly thermal treatments now researched $[80,81]$.

Larachi et al. [82] reported that low pressure direct gas-solid carbonation of chrysotile residues led to poor conversions, at best achieving $3.3 \%$ extent after 10 hours at $375^{\circ} \mathrm{C}$, via surface impregnation of superbasic sites or amorphisation/dehydroxylation. Conversely, Larachi et al. [77] report that partial dehydroxylation and steam mediation substantially enhance conversion, reaching uptakes as high as $0.7 \mathrm{CO}_{2}$ moles per $\mathrm{Mg}$ mole at $130^{\circ} \mathrm{C}$ and $3.2 \mathrm{MPa}$. Ryu et al. [83] investigated the direct aqueous carbonation of chrysotile under subcritical conditions in alkali solution. The starting material was hydrothermally treated at $\mathrm{pH}=13$, at $100^{\circ} \mathrm{C}$ and $\mathrm{CO}_{2}$ partial pressures between 0.5 and $4 \mathrm{MPa}$. As the reaction proceeded, the surface morphology of chrysotile was observed to change from acicular (needle-like) and cylindrical-like forms, to a round or oval shape initially, and later to highly crystalline magnesite. The carbonation rate increased proportionally to the applied $\mathrm{CO}_{2}$ pressure up to $57 \%$ at $3 \mathrm{MPa}$. Ryu et al. [84] carried out direct aqueous carbonation of tremolite $\left(\mathrm{Ca}_{2} \mathrm{Mg}_{5} \mathrm{Si}_{8} \mathrm{O}_{22}(\mathrm{OH})_{2}\right)$, another of the six types of asbestos, at $290^{\circ} \mathrm{C}$ and 5 bar $\mathrm{CO}_{2}$. Figure 4 shows the evolution of the material as a function of carbonation time. A significant amount of fibrous tremolite was transformed to calcite $\left(\mathrm{CaCO}_{3}\right)$, which made up $60 \mathrm{wt} \%$ of the final material. Tremolite carbonation was coupled with a saponitization reaction, as the crystallization of calcite was systematically associated with proto-saponite $\left(\mathrm{Ca}_{0.25}(\mathrm{Mg}, \mathrm{Fe})_{3}\left((\mathrm{Si}, \mathrm{Al})_{4} \mathrm{O}_{10}\right)(\mathrm{OH})_{2}\right.$. $\left.n\left(\mathrm{H}_{2} \mathrm{O}\right)\right)$. Also, it was shown that the fibrous shape of tremolite transformed to a rhombohedral or round shape 
during the carbonation reaction, which is environmentally friendlier. Gadikota et al. [85] carbonated hazardous asbestos containing material (ACM) in various reaction fluids (D.I. water, 0.1 M Na-oxalate, and $1.0 \mathrm{M} \mathrm{Na-}$ acetate), at varying temperature $\left(90,125\right.$, and $\left.185^{\circ} \mathrm{C}\right)$, in $150 \mathrm{~atm} . \mathrm{CO}_{2}$, with a stirring speed of $800 \mathrm{rpm}$, for 3 hours. Despite low conversions (max. 10.2\%), significant changes in the structure (particle size and pore size) were observed due to mixing and simultaneous dissolution of ACM. Na-oxalate was found to be more effective than Na-acetate despite the lower concentration, which was attributed to it being a stronger magnesium-targeting chelating agent.

The tailings produced during mineral processing of non-ferrous ores, such as nickel and platinum group metals (PGM), can also contain significant amounts of magnesium silicates, and thus are potential carbon sinks. Meyer et al. [86] presented results on carbonation using the two-stage $\mathrm{pH}$-swing of $\mathrm{Mg}$-orthopyroxene rich tailings generated during the processing of platinum ores from South Africa. For the cation extraction, organic (oxalic and EDTA) and $\mathrm{HCl}$ solutions were used, followed by $\mathrm{NaOH}$ addition for $\mathrm{pH}$ adjustment before carbonation. The extraction efficiencies of $\mathrm{Mg}, \mathrm{Ca}$ and $\mathrm{Fe}$ from the $2 \mathrm{M} \mathrm{HCl}$ was rapid for the first 30 minutes. Afterwards, the reaction slowed, and after 4 hours of reacting the dissolution of $\mathrm{Mg}$ and $\mathrm{Fe}$ reached a plateau. After 8 hours of reaction, however, $\mathrm{Ca}$ had not yet reached a plateau. Ca ions had the highest extraction efficiency of $31.2 \%$, followed by $\mathrm{Fe}$ at $9.1 \%$ and $\mathrm{Mg}$ at $5.0 \%$. SEM and XRD analysis of the carbonate precipitate revealed the formation of both unstable (readily decomposing or dissolving) and stable carbonates. The unstable carbonates consisted of: trona $\left(\mathrm{Na}_{3}\left(\mathrm{CO}_{3}\right)\left(\mathrm{HCO}_{3}\right) \cdot 2\left(\mathrm{H}_{2} \mathrm{O}\right)\right)$, natrite $\left(\mathrm{Na}_{2} \mathrm{CO}_{3}\right)$ and thermonatrite $\left(\mathrm{Na}_{2} \mathrm{CO}_{3} \cdot\left(\mathrm{H}_{2} \mathrm{O}\right)\right)$, which formed the bulk, by weight, of the products. The stable carbonates formed were: gaylussite $\left(\mathrm{Na}_{2} \mathrm{Ca}\left(\mathrm{CO}_{3}\right)_{2} \cdot 5\left(\mathrm{H}_{2} \mathrm{O}\right)\right)$, siderite $\left(\mathrm{FeCO}_{3}\right)$, ankerite $\left(\mathrm{Ca}(\mathrm{Mg}, \mathrm{Fe})\left(\mathrm{CO}_{3}\right)_{2}\right)$, dolomite $\left(\mathrm{CaMg}\left(\mathrm{CO}_{3}\right)_{2}\right)$, and hydromagnesite $\left(\mathrm{Mg}_{5}\left(\mathrm{CO}_{3}\right)_{4}(\mathrm{OH})_{2} \cdot 4 \mathrm{H}_{2} \mathrm{O}\right)$. It was found that orthopyroxene, which comprises $88 \%$ of the total $\mathrm{Mg}$ budget in this kind of waste, remained unreacted; thus further work is needed to improve its dissolution kinetics before such mineral tailings can be considered as a viable feed stock for mineral carbonation.

\subsection{Red mud}

Red mud is a by-product of the process for obtaining alumina from bauxite ore through the Bayer process. Red mud is considered a hazardous waste, especially due to high alkalinity, and also a critical waste management
Table 3. Average chemical composition of red mud; expressed as oxides [87].

\begin{tabular}{ll}
\hline Oxide & Amount $(\mathbf{w t} \%)$ \\
\hline $\mathrm{Al}_{2} \mathrm{O}_{3}$ & $2-33$ \\
$\mathrm{Fe}_{2} \mathrm{O}_{3}$ & $7-72$ \\
$\mathrm{SiO}_{2}$ & $1-24$ \\
$\mathrm{TiO}_{2}$ & $3-23$ \\
$\mathrm{CaO}$ & $1-47$ \\
$\mathrm{Na}_{2} \mathrm{O}$ & $1-13$ \\
\hline
\end{tabular}

issue, given the large quantities annually produced. Red mud consists of a mixture of liquid in chemical equilibrium with fine solids $(20-80 \mathrm{wt} \%)$, the particles size of which varies between 2-100 $\mu \mathrm{m}$, having a chemical composition typically in the range presented in Table 3. The $\mathrm{pH}$ of red mud averages at $11.3 \pm 1.0$, but can reach as high as 12.9. The $\mathrm{pH}$ is highly buffered by the presence of alkaline solids (hydroxides, carbonates and aluminates) that are formed during caustic soda $(\mathrm{NaOH})$ treatment of bauxite [87]; residual $\mathrm{NaOH}$ in the liquid phase is also a major contributor to the high $\mathrm{pH}$. The complex buffering actions of the multiple components of red mud makes it impractical to 'wash out' the alkalinity. Thus red mud is commonly stored in settling ponds, which have come to pose significant threat to neighboring populations and the environment. Yet, Si et al. [88] report that an estimated 100 million tonnes of $\mathrm{CO}_{2}$ have been unintentionally sequestered in stored red mud worldwide by its natural weathering. Based on current production rates, about 6 million tonnes of $\mathrm{CO}_{2}$ will be sequestered annually through atmospheric carbonation. Si et al. [88] estimate that if appropriate carbonation technologies are applied to red mud, an additional 6 million tonnes of $\mathrm{CO}_{2}$ can be potentially captured and stored, while the hazardousness of red mud is simultaneously reduced. Since 2006, carbonation has been employed as a pre-deposition $\mathrm{pH}$ reduction treatment at the Kwinana refinery in Western Australia, where carbon dioxide gas is mixed with the residue slurry in pressurized vessels, after thickening of the mud to remove excess liquor [89].

The carbonation of red mud implies a pre-carbonation decision: carbonate the red mud liquid-solid mixture, or the drained solids. Bonenfant et al. [90] found that predried red mud suspension at a liquid-to-solid ratio of $10 \mathrm{~kg} / \mathrm{kg}$ has a realizable $\mathrm{CO}_{2}$ storage capacity of only $4.15 \mathrm{~g} \mathrm{CO}_{2} / 100 \mathrm{~g}$ red mud when carbonated at $20^{\circ} \mathrm{C}$ and 15 vol\% $\mathrm{CO}_{2}$ at atmospheric pressure, which is attributed to carbonation of its $\mathrm{Ca}$ - and $\mathrm{Na}$-(hydr)oxide contents. Yadav et al. [91] report similar $\mathrm{CO}_{2}$ uptake (3.5 wt\%) after pressurized (3.5 bar) carbonation of washed red mud solids. Bonenfant et al. [90] propose that because the red mud matrix has a great leaching capacity of 


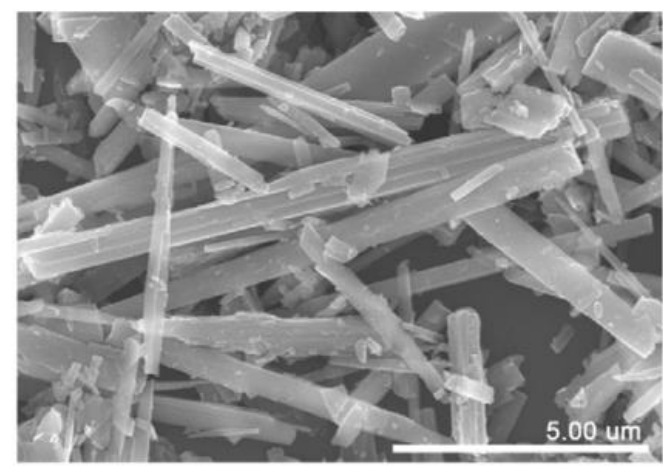

(a)

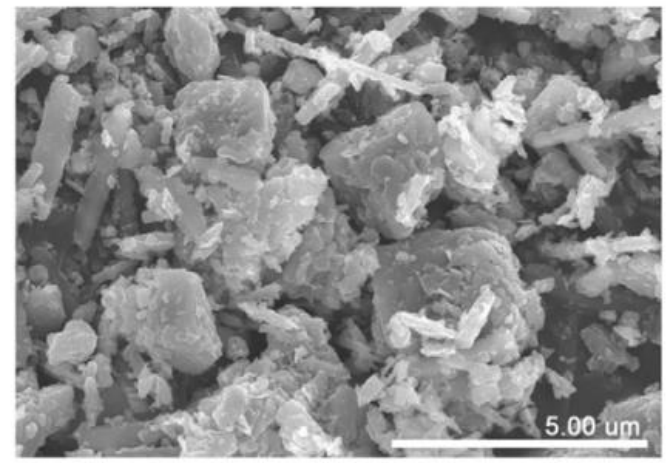

(c)

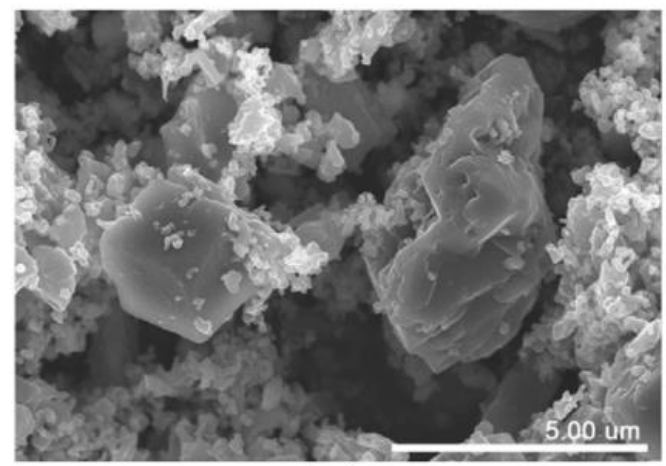

(e)

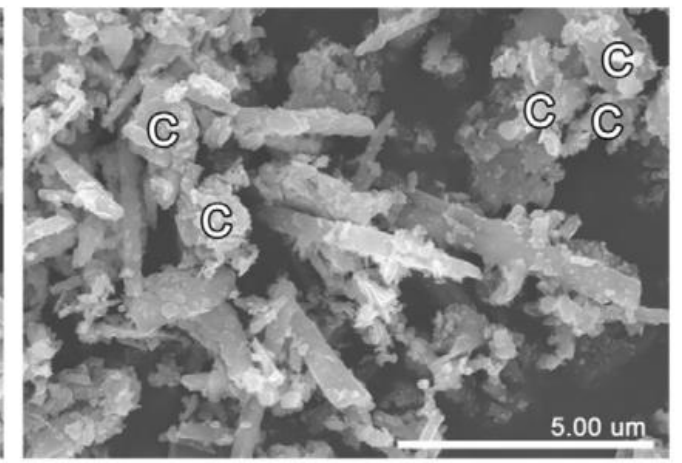

(b)

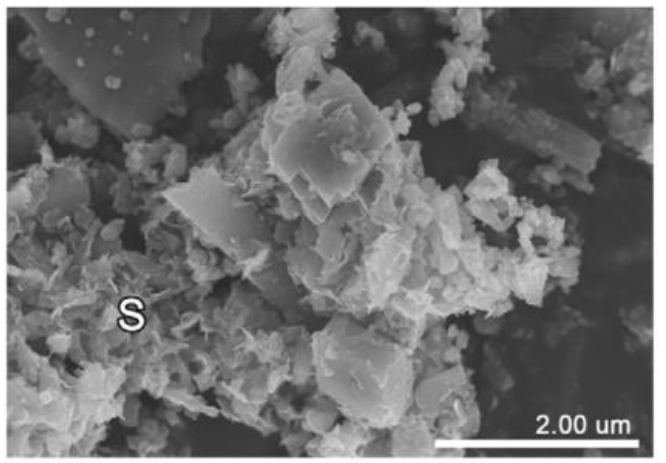

(d)

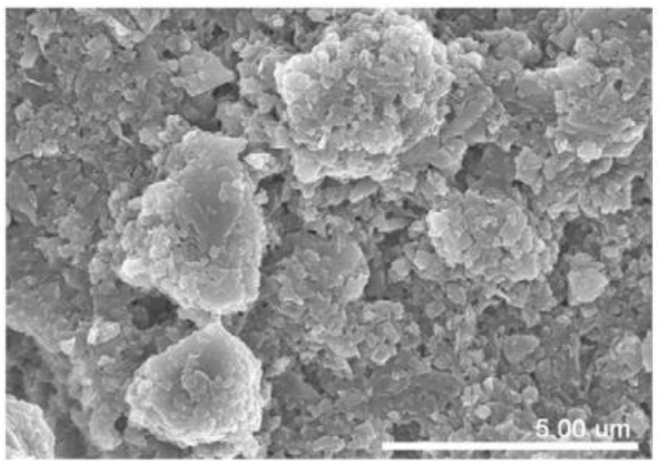

(f)

Figure 4. Evolution of tremolite carbonation: (a) acicular tremolite; (b) development of $\mathrm{i} 1 \mu \mathrm{m}$-sized calcite after 5 min of reaction; (c) image after carbonation for $15 \mathrm{~min}$; ( $\mathrm{d}$ and e) the shape of most of the tremolite grains changed to round and calcite shows euhedral morphology. The calcite with rhombohedral cleavage was surrounded by saponite of the "curled flake type" after reaction for $1 \mathrm{~h}$. (f) The edge of calcite was eroded by partial dissolution during the reaction for $5 \mathrm{~h}$. $\mathrm{C}$ and $\mathrm{S}$ indicate calcite and saponite, respectively. Reprinted from Applied Geochemistry, Vol. 26, Ryu et al. [84], 1215-1221, Copyright 2011, with permission from Elsevier.

$\mathrm{Na}$-(hydr)oxide, the alternated carbonation of leachates separated from the leached hydrated-matrixes of red mud could constitute a more effective method for the $\mathrm{CO}_{2}$ sequestration than the use of aqueous red mud suspension. Sahu et al. [92] employed cyclic carbonation of red mud solids, 5 hours in duration each cycle, in aqueous slurry at atmospheric pressure. The $\mathrm{pH}$, alkalinity and acid neutralization capacity (ANC) of the red mud decreased from $\sim 11.8$ to $\sim 8.45, \sim 10,789$ to $\sim 178 \mathrm{mg} / \mathrm{L}$, and $\sim 1.3$ to $\sim 0.23 \mathrm{~mol} \mathrm{H}^{+} / \mathrm{kg}$, respectively, at the end of the third cycle. The cost for sequestering a tonne of $\mathrm{CO}_{2}$ was estimated at approximately \$147, and the quantity of 
sequestered $\mathrm{CO}_{2}$ was about $7.02 \mathrm{~g}$ per $100 \mathrm{~g}$ red mud. Khaitan et al. [93] noted that the $\mathrm{pH}$ of carbonated red mud rebounded to 9.9 after one day, indicating that the $\mathrm{pH}$ change during short-term ( $\leq 10$ days) carbonation is due to the reaction of carbonic acid and $\mathrm{OH}^{-}$in the pore water. Only after a longer reaction time (30 days) at 1 atm. $\mathrm{CO}_{2}$ did tricalcium aluminate $\left(\mathrm{Ca}_{3} \mathrm{Al}_{2} \mathrm{O}_{6}\right)$ in the solid phase convert to calcite, as was observed from aged field samples that had been carbonated in air $\left(10^{-3.5} \mathrm{~atm} . \mathrm{CO}_{2}\right)$ for 30 years.

Dilmore et al. [94] utilized a different route for the carbonation treatment of red mud. Instead of carbonating only the red mud, it was mixed with an industrial brine (saline wastewater) solution of low $\mathrm{pH}(\sim 3)$ and rich in $\mathrm{Ca}^{2+}$ and $\mathrm{Mg}^{2+}$. In this case, the high $\mathrm{pH}(\sim 13)$ red mud actually acted as a $\mathrm{pH}$ buffer, to induce the carbonate formation from the brine solution constituents, while at the same time becoming neutralized itself. A bauxite residue/brine mixture of $90 / 10$ by volume exhibited a $\mathrm{CO}_{2}$ sequestration capacity of $9.5 \mathrm{~g} / \mathrm{L}$ at $20^{\circ} \mathrm{C}$ and 6.89 bar $\mathrm{CO}_{2}$, and reached a final $\mathrm{pH}$ of $\sim 7$. Soong et al. [95] applied a similar process scheme, but using $\mathrm{SO}_{2}$-containing flue gas instead of pure $\mathrm{CO}_{2}$. They found that $>99.9 \%$ of the $\mathrm{SO}_{2}$ was captured in the carbonated red mud/brine mixture, in the form of sulfite $\left(\mathrm{SO}_{3}^{2-}\right)$ by solubility trapping.

\subsection{Oil-shale processing residues}

A particular line of research that has been undertaken in the last few years is that of the utilization of Estonian oil-shale ashes for carbon capture [96-98]. Combustion of oil-shale by means of pulverized firing (PF) and in circulating fluidized bed combustors (CFBCs) produces ashes that contain up to $30 \mathrm{wt} \%$ free $\mathrm{Ca}$ - and $\mathrm{Mg}$ oxides. Uibu et al. [96] conducted carbonation experiments using a model gas whose composition (10 wt\% $\mathrm{CO}_{2}$ and $90 \mathrm{wt} \%$ air) simulated the flue gases formed during oil-shale combustion. The carbonation was performed with solid/liquid ratio of $1: 10$ at ambient temperature and atmospheric pressure. CFBC ashes carbonated more than PF ashes: $83-98 \%$ and $48-73 \%$ conversion, respectively, equivalent to $100-160 \mathrm{~kg} \mathrm{CO} /$ tonne binding capacity. The alkaline ash transportation water was also neutralized with $\mathrm{CO}_{2}$, and resulted in rapid neutralization and retention of $52 \mathrm{~kg} \mathrm{CO}$ by the amount of alkaline wastewater used for transporting 1 tonne of ash. In Uibu and Kuusik [97], the superior carbonation performance of CFBC ashes was attributed to its more porous particle structure, which allowed better diffusion of $\mathrm{Ca}^{2+}$ ions into solution. In the case of PF ash, process deceleration was caused by the concurrence of two factors: low porosity of PF ash, and high concentration of dissolved salts in the liquid phase inhibiting diffusion of $\mathrm{Ca}^{2+}$ away from the solid surface. These factors led to the formation of insoluble layers of $\mathrm{CaCO}_{3}$ and $\mathrm{CaSO}_{4}$ that partially or completely prevented further dissolution of $\mathrm{CaO}$. To overcome this limitation, a continuous-flow reactor was designed and tested, where the composition of the liquid phase contacting ash could be monitored and controlled. It consisted of reactor-columns working in cascade (Figure 5a), wherein the $\mathrm{pH}$ levels in the different reactors ranged from alkaline to almost neutral, thus delivering optimal conditions for lime slaking, $\mathrm{Ca}(\mathrm{OH})_{2}$ dissociation and $\mathrm{CaCO}_{3}$ precipitation. Final carbonated ashes contained $0.6-2.9 \mathrm{wt} \%$ of unreacted $\mathrm{CaO}$ and 17-20 wt\% $\mathrm{CO}_{2}$.

\section{Valorization of treated industrial wastes}

For mineral carbonation to become economically feasible, the valorization of the resulting material could help reduce the overall cost of the process. This section outlines some of the latest developments with this objective, mainly for the production of construction materials that either contain carbonated products, or that are formed by means of carbonation.

Monkman et al. [99] studied the possibility of using carbonated ladle (BOF) steel slag as a fine aggregate in concrete. Carbonation was performed both at $500 \mathrm{kPa}$ $\mathrm{CO}_{2}$ for 2 hours and at atmospheric pressure for 56 days. The main objective was to reduce the free lime $(\mathrm{CaO})$ content. Slag particles between $300-600 \mu \mathrm{m}$ sequestered $4.2 \mathrm{wt} \% \mathrm{CO}_{2}$, and those smaller than $75 \mu \mathrm{m}$ carbonated to $15.6 \mathrm{wt} \% \mathrm{CO}_{2}$. The extractable $\mathrm{CaO}$ contents were significantly reduced by carbonation treatment. The carbonated slag was then used as a fine aggregate in zero-slump press-formed compact mortar samples; similar mortars made instead with river sand as the fine aggregate were used as controls. After 28 days of moist curing, the strength of the mortars was comparable. As such, the use of carbonated ladle slag appears to be a suitable substitute as a fine aggregate in concrete.

Salman et al. [100] used continuous casting stainless steel slag with particle diameter $<500 \mu \mathrm{m}$ to fabricate cylindrical specimens of $55 \mathrm{~mm}$ in diameter and $75 \mathrm{~mm}$ in height. These specimens were then carbonated using two methods (mild conditions in an incubator, and high temperature and pressure using an autoclave reactor). While a period of 4 weeks was needed to reach the highest compressive strength $(20 \mathrm{MPa})$ by incubator carbonation ( 5 vol\% $\mathrm{CO}_{2}, 22^{\circ} \mathrm{C}$ and $80 \%$ humidity), only 
(a) ash, $2.6 \mathrm{~kg} / \mathrm{h}$

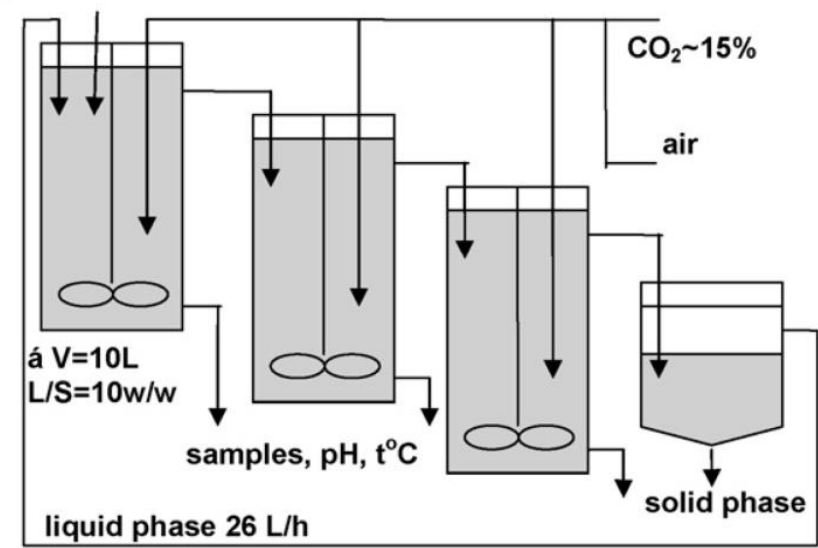

(b)

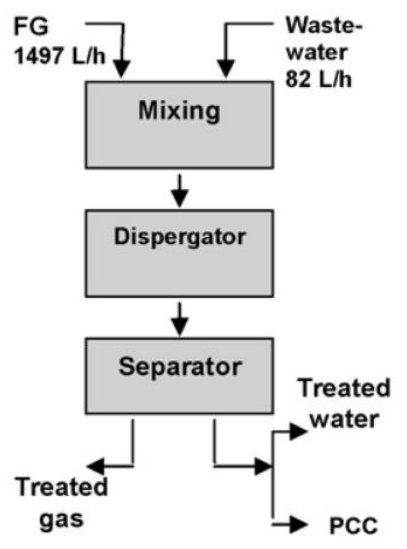

Figure 5. Experimental cascading reactors for carbonation of oil-shale ash suspension (a) and alkaline wastewater (b). Reprinted from Journal of Hazardous Materials, Vol. 174, Uibu et al. [98], 209-214, Copyright 2009, with permission from Elsevier.

6 hours was needed to reach similar strength when using autoclave reactor carbonation at 8 bar, $\mathrm{CO}_{2}$ and $60^{\circ} \mathrm{C}$. This compressive strength can make such materials suitable for several structural and non-structural applications.

Van Mechelen et al. [101] have worked on the upscaling of the Carbstone process, developed for the valorization of non-hydraulic slags and ashes into high quality construction materials. The process makes use of accelerated carbonation by treating various kinds of compacted slags with $\mathrm{CO}_{2}$ at elevated pressure (520 bar) and temperature (up to $140^{\circ} \mathrm{C}$ ) without addition of binders. The carbonation process consists of three essential steps: (1) pretreatment of the slags, (2) shaping of the building blocks by compaction, and (3) curing of the building block by $\mathrm{CO}_{2}$. The carbonates that are produced in-situ during the carbonation reaction act as a binder, cementing the slag particles together. The carbonated materials can compete with concrete products (C35/C45), having satisfactory environmental and technical properties. Furthermore, the materials sequester 180-200 $\mathrm{g} \mathrm{CO}_{2} / \mathrm{kg}$ slag.

Baciocchi et al. [102] used ground basic oxygen furnace (BOF) slag (particle size $<2 \mathrm{~mm}$ ) mixed with water to produce granulates of particle diameter up to $9 \mathrm{~mm}$. This granulation was realized with and without carbonation. Leaching tests conducted after the granulation experiments indicate that select elements (e.g. $\mathrm{K}, \mathrm{Na}$ and $\mathrm{Ba}$ ) appeared to be more tightly bound to the solid matrix. The same decreasing trend was also observed for the $\mathrm{pH}$ and the apparent particle density. The ultimate goal of this work was the production of aggregates for use in construction works, thus aggregate crushing value (ACV) tests were performed on the granulated slag and natural gravel as a control. The results showed that the amount of fine particles ( $d<2.36 \mathrm{~mm}$ ) obtained was significantly higher (over $70 \mathrm{wt} \%$ of the material) than that achieved for natural gravel $(20 w t \%)$, so further optimization is required.

Gunning et al. [103] have reported the latest developments of the spin-out company Carbon8 Systems Ltd, which is developing an industrial process for the production of lightweight aggregates from waste materials via accelerated carbonation. The favored waste material is municipal solid waste incineration (MSWI) air pollution control residues (APCr), which originates from flue gas treatment where lime, carbon, and ammonia are added to neutralize $\mathrm{pH}$ and remove pollutants such as dioxins and volatile metals. The patented process [104] begins with APCr passing through a treatment chamber, where initial carbonation of the APC $r$ takes place. Next it enters a batch mixer where reagents are introduced to produce a mixture that is then conveyed to the pelletizing unit. There, the materials are aggregated with further addition of $\mathrm{CO}_{2}$, which induces chemical stabilization and solidification of the aggregate (exemplified in Figure 6). The aggregated product is then valorized in an on-site concrete block making process. Compliance of the aggregate product is determined based on physical properties (compressive strength, particle size and durability), and chemical characteristics (leaching of metals and anions). Specifically, to conform to Endof-Waste specifications, an average individual aggregate 


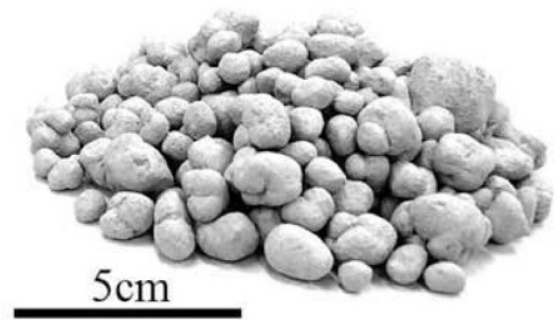

Figure 6. Pelletized lightweight aggregate product. Reprinted from Waste Management, Vol. 29, Gunning et al. [105], 27222728, Copyright 2009, with permission from Elsevier.

compressive strength of $0.1 \mathrm{MPa}$, and a maximum bulk density of $1200 \mathrm{~kg} / \mathrm{m}^{3}$ are required. Gunning et al. [103] shows that these requirements are consistently met $\left(\sim 0.28 \mathrm{MPa}\right.$ and $\left.\sim 1120 \mathrm{~kg} / \mathrm{m}^{3}\right)$ at a full-scale facility with a production capacity of 36,000 tonne/yr.

On a research sphere outside that of construction materials, Uibu et al. [98] identified a second opportunity for carbonation within oil-shale power plants, namely using the $\mathrm{Ca}^{2+}$-saturated alkaline water $(\mathrm{pH} 12-13)$ that is recycled between the plant and sedimentation ponds for the transport of the ash to wet open-air deposits. The goal was to intensify the water neutralization process and use the wastewater as a calcium source for the production of precipitated calcium carbonate (PCC) (Figure 5b). The PCC formed was characterized by a regular rhombohedral structure and a homogeneous particle size $(\sim 5 \mu \mathrm{m})$ distribution. It was also found that to avoid agglomeration of the particles and re-dissolution of $\mathrm{CaCO}_{3}$, the neutralization process should be divided into two stages: PCC precipitation and separation at high $\mathrm{pH}$ values in a first stage, followed by decreasing the residual alkalinity of the wastewater to acceptable disposal levels $(\mathrm{pH} \sim 8-8.5)$ in a second stage.

\section{Conclusions}

As part of the CCS concept, mineral carbonation (sequestration) of $\mathrm{CO}_{2}$ was initially applied to natural minerals. Once the proof of concept was established and the technology mechanisms reasonably well understood, the focus also turned to the utilization of alkaline industrial wastes, which were found, in large part, to be not only more reactive (compared to serpentine and olivine, for example), but also easily and (geographically) widely available. Even if available in smaller quantities compared to resources of natural silicate minerals, alkaline wastes can still sequester meaningful quantities of $\mathrm{CO}_{2}$, especially as many of these residues are generated near large point sources of $\mathrm{CO}_{2}$ [24]. Mineral carbonation can thus constitute a decentralized approach to CCS [106]. A further benefit identified when utilizing waste materials for mineral carbonation, besides serving as carbon sinks, has been the possibility of stabilizing some of the detrimental properties of these materials (e.g. leaching/toxicity), and valorizing them, either by reducing treatment, disposal and storage costs, or producing materials that can be safely re-utilized commercially.

However, the chemical, mineralogical and morphological properties of these materials also vary widely, impacting their behavior towards carbonation and the resulting effects of carbonation. As such, only recently has a large enough body of research formed to investigate the many opportunities available and develop the necessary material-specific intensified carbonation processes. This paper reviewed the latest developments in this field, focusing on the beneficial effects of mineral carbonation when applied to metallurgical slags, incineration ashes, mining tailings, asbestos containing materials, red mud and oil shale processing residues, and on the valorization opportunities closest to making the transition from laboratory research to commercial reality, particularly in the form of shaped construction materials and precipitated calcium carbonate.

Several challenges still remain to enable large-scale and widespread adoption of mineral carbonation as an industrial process. Processing costs still need to be reduced, especially in view of reducing external energy input and maximizing the utilization of the exothermic carbonation heat of reaction. To this end, efforts are being made to intensify the carbonation reaction rate and improve the mineral conversion via process intensification routes, such as the application of ultrasound [26], hot-stage processing [40] and integrated reactor technologies [13]. Geochemical and mineralogical mechanisms also need to be investigated in greater depth. For example, the relationship between microstructure and leaching, and the susceptibility of individual mineral phases to hydration and mineral carbonation, are only starting to be clarified [27, 76].

Besides technical challenges, practical issues also need to be overcome. One such barrier is the lack of economical reward for the capture of $\mathrm{CO}_{2}$, as well as for the valorization of waste materials. The industrial mindset focuses on maximizing profit, and thus most attention is given to increasing the production efficiency of the principal products (e.g. steel), rather than applying large efforts to waste treatment and management. It appears that only legislative mandates can compel industry 
to change its attitude, though greater awareness by the industry and young engineers of sustainable green technologies, including mineral carbonation, may slowly buck the trend.

Another challenge faced by mineral carbonation technologies is the competition for attention with alternative CCS technologies, especially underground storage. Mineral carbonation does have the possibility to capture all anthropogenic $\mathrm{CO}_{2}$ emissions, given the amount of suitable minerals present in the Earth's crust [7]. Mineral carbonation also presents additional benefits, including geochemically permanent $\mathrm{CO}_{2}$ storage without leakage risk, as well as valorization opportunities through the commercialization of the formed carbonate materials. Still, underground storage, presently, presents lower costs and more scalable opportunities, so it is understandable that it remains as the lead option for CCS. This should not mean that mineral carbonation research is not important; in fact the opposite holds true: more investment should directed towards to mineral carbonation so that it eventually can become the preferred CCS route, capitalizing on its evident advantages. As such, a greater level of industrial cooperation and governmental support is needed. Two such examples are the KU Leuven's Knowledge Platform on Sustainable Materialization of Residues from Thermal Processes into Products (SMaRT-Pro ${ }^{2}$ ) and Research Consortium on Sustainable Inorganic Materials Management $\left(\mathrm{SIM}^{2}\right)$, hosts of the Fourth International Conference on Accelerated Carbonation for Environmental and Materials Engineering (ACEME 2013).

\section{Acknowledgements}

Bodor Marius would like to acknowledge the support provided by the European Union, Romanian Government and "Dunarea de Jos" University of Galati, through the project POSDRU - 107/1.5/S/76822. Rafael Santos and Tom Van Gerven acknowledge funding from the KU Leuven Industrial Research Fund (IOF) for the SMaRT$\mathrm{Pro}^{2}$ Knowledge Platform. Rafael Santos is also grateful for PGS-D financial support from the Natural Sciences and Engineering Research Council of Canada (NSERC).

\section{References}

[1] NOAA ESRL, Trends in Atmospheric Carbon Dioxide [Online], Available at: http://www.esrl.noaa.gov/ gmd/ccgg/trends/history.html [accessed March 4, 2013]
[2] Lackner K. S., Capture of carbon dioxide from ambient air, Eur. Phys. J. Special Topics, 2009, 176, 93-106

[3] House K. Z., Baclig A. C., Ranjan M., van Nierop E. A. et al., Economic and energetic analysis of capturing $\mathrm{CO}_{2}$ from ambient air, PNAS, 2011, 108(51), 20428-20433

[4] Lackner K. S., Brennan S., Matter J. M., Park A. $\mathrm{H}$. A. et al., The urgency of the development of $\mathrm{CO}_{2}$ capture from ambient air, PNAS, 2012, 109(33), 13156-13162

[5] Goeppert A., Czaun M., Prakash G. K. S., Olah G. A., Air as the renewable carbon source of the future: an overview of $\mathrm{CO}_{2}$ capture from the atmosphere, Energy Environ. Sci., 2012, 5(7), 7833-7853

[6] Bennaceur K., Monea M., Sakurai S., Gupta N. et al., $\mathrm{CO}_{2}$ Capture and storage - A solution within, Oilfield Review, 2004, 16, 44-61

[7] Lackner K. S., A Guide to $\mathrm{CO}_{2}$ Sequestration, Science, 2003, 300(5626), 1677-1678

[8] Harvey O. R., Cantrell K. J., Qafoku N. P., Brown C. F., Geochemical Implications of $\mathrm{CO}_{2}$ Leakage Associated with Geologic Storage: A Review, Report prepared for the U.S. Department of Energy under Contract DE-AC05-76RL01830, 2012

[9] Paulley A., Maul P., Metcalfe R., Scenarios for Potential Impacts from Hypothetical Leakage from Geological Storage Facilities for Carbon Dioxide, Public deliverable from the RISCS project, 2012

[10] Sipilä J., Teir S., Zevenhoven R., Carbon dioxide sequestration by mineral carbonation - Literature review update 2005-2007, ISBN 978-952-12-20364, 2008

[11] Seifritz W., $\mathrm{CO}_{2}$ disposal by means of silicates, Nature, 1990, 345(6275), 486

[12] Santos R. M., Van Gerven T., Process intensification routes for mineral carbonation, Greenhouse Gas Sci. Technol., 2011, 1(4), 287-293

[13] Santos R. M., Verbeeck W., Knops P., Rijnsburger K. et al., Integrated mineral carbonation reactor technology for sustainable carbon dioxide sequestration: ' $\mathrm{CO}_{2}$ Energy Reactor', Energy Procedia, 2013a, doi:10.1016/j.egypro.2013.06.513

[14] Van Gerven T., Leaching of Heavy Metals from Carbonated Waste-Containing Construction Material, $\mathrm{PhD}$ Thesis, Katholieke Universiteit Leuven, Leuven, Belgium, 2005

[15] Huijgen W. J. J., Carbon dioxide sequestration by mineral carbonation, $\mathrm{PhD}$ Thesis, Technische Universiteit Delft, Delft, The Netherlands, 2007

[16] Rawlins C. H., Geological Sequestration of Carbon Dioxide by Hydrous Carbonate Formation in 
Steelmaking Slag, PhD Thesis, Missouri University of Science and Technology, Rolla, Missouri, USA, 2008

[17] Teir S., Fixation of carbon dioxide by producing carbonates from minerals and steelmaking slags, PhD Thesis, Helsinki University of Technology, Espoo, Finland, 2008

[18] Uibu M., Abatement of $\mathrm{CO}_{2}$ emissions in Estonian oil shale-based power production, $\mathrm{PhD}$ Thesis, Tallinn University of Technology, Tallinn, Estonia, 2008

[19] Costa G., Accelerated carbonation of minerals and industrial residues for carbon dioxide storage, PhD Thesis, Universitá Degli Studi Di Roma "Tor Vergata", Rome, Italy, 2009.

[20] Eloneva S., Reduction of $\mathrm{CO}_{2}$ emissions by mineral carbonation: steelmaking slags as raw material with a pure calcium carbonate end product, PhD Thesis, Aalto University, Espoo, Finland, 2010

[21] Gunning P. J., Accelerated Carbonation of Hazardous Wastes, PhD Thesis, University of Greenwich, Chatham Maritime, United Kingdom, 2011

[22] ACEME'10, Third International Conference on Accelerated Carbonation for Environmental and Materials Engineering [Online], Available at: http: //web.abo.fi/fak/tkf/vt/aceme10/ [accessed March 4, 2013]

[23] ACEME'13, Fourth International Conference on Accelerated Carbonation for Environmental and Materials Engineering [Online], Available at: http: //cit.kuleuven.be/aceme13/ [accessed March 4, 2013]

[24] Bobicki E. R., Liu Q., Xu Z., Zeng H., Carbon capture and storage using alkaline industrial wastes, Prog. Energy Combust. Sci., 2012, 38, 302-320

[25] Baciocchi R., Costa G., Bartolomeo E., Polettini A. et al., Carbonation of Stainless Steel Slag as a Process for $\mathrm{CO}_{2}$ Storage and Slag Valorization, Waste Biomass Valorization, 2010a, 1, 467-477

[26] Santos R. M., François D., Mertens G., Elsen J. et al., Ultrasound intensified mineral carbonation, Appl. Therm. Eng., 2013b, 57, 154-163

[27] Bodor M., Santos R. M., Kriskova L., Elsen J. et al., Susceptibility of mineral phases of steel slags towards mineral carbonation: mineralogical, morphological and chemical assessment, Eur. J Mineral., 2013, doi:10.1127/0935-1221/2013/00252300

[28] IPCC, Carbon Dioxide Capture and Storage Summary for Policymakers, ISBN 92-9169-119-4, 2005
[29] Huijgen W. J. J., Comans R. N. J., Witkamp G. -J., Cost evaluation of $\mathrm{CO}_{2}$ sequestration by aqueous mineral carbonation, Energy Convers Manage., 2007, 48, 1923-1935

[30] Chang E. -E., Chen C. -H., Chen Y. -H., Pan S. Y. et al., Performance evaluation for carbonation of steel-making slags in a slurry reactor, J. Hazard Mater., 2011, 186, 558-564

[31] Chang E. -E., Chiu A. -C., Pan S. -Y., Chen Y. $\mathrm{H}$. et al., Carbonation of basic oxigen furnace slag with metalworking wastewater in a slurry reactor, Int. J. Greenhouse Gas Control, 2013, 12, 382-389

[32] Gogate P. R., Sutkar V. S., Pandit A. B., Sonochemical reactors: important design and scale up considerations with a special emphasis on heterogeneous systems, Chem. Eng. J., 2011, 166, 1066-1082

[33] Wagterveld R. M., Boels L., Mayer M. J., Witkamp G. J., Visualization of acoustic cavitation effects on suspended calcite crystals, Ultrason. Sonochem., 2011, 18, 216-225

[34] Steinour H. H., Some effects of carbon dioxide on mortars and concrete-discussion, Concrete Briefs, J. Am. Concr. Inst., 1959, 55, 905-907

[35] Doucet F. J., Effective $\mathrm{CO}_{2}$-specific sequestration capacity of steel slags and variability in their leaching behaviour in view of industrial mineral carbonation, Miner. Eng., 2010, 23, 262-269

[36] Reddy E. P., Smirniotis, P.G., High-temperature sorbents for $\mathrm{CO}_{2}$ made of alkali metals doped on CaO supports, J. Phys. Chem. B, 2004, 108, 77947800

[37] Blamey J., Anthony E. J., Wang J., Fennell P. S., The calcium looping cycle for large-scale $\mathrm{CO}_{2}$ capture, Prog. Energy Combust. Sci., 2010, 36, 260-279

[38] Manovic V., Anthony E. J., Lime-based sorbents for high-temperature $\mathrm{CO}_{2}$ capture-a review of sorbent modification methods, Int. J. Environ. Res. Public Health, 2010, 7, 3129-3140

[39] Prigiobbe V., Polettini A., Baciocchi R., Gassolid carbonation kinetics of Air Pollution Control residues for $\mathrm{CO}_{2}$ storage, Chem. Eng. J., 2009, 148, 270-278.

[40] Santos R. M., Ling D., Sarvaramini A., Guo M., Elsen J., Larachi F., Beaudoin G., Blanpain B., Van Gerven T., Stabilization of basic oxygen furnace slag by hot-stage carbonation treatment, Chem. Eng. J., 2012, 203, 239-250

[41] Bonfils B., Julcour-Lebigue C., Guyot F., Bodénan F., Chiquet P., Bourgeois F., Comprehensive analysis of direct aqueous mineral carbonation using dissolution enhancing organic additives, Int. J. 
Greenhouse Gas Control, 2012, 9, 334-346.

[42] Chiang Y. W., Santos R. M., Elsen J., Meesschaert B., Martens J. A., Van Gerven T., Two-way valorization of blast furnace slag into precipitated calcium carbonate and sorbent materials, In: Proceedings of the Fourth International Conference on Accelerated Carbonation for Environmental and Materials Engineering (April 9-12, 2013 Leuven Belgium), 2013, 355-365

[43] Eloneva S., Teir S., Salminen J., Fogelholm C. J., Zevenhoven R., Steel Converter Slag as a Raw Material for Precipitation of Pure Calcium Carbonate, Ind. Eng. Chem. Res., 2008, 47, 71047111

[44] Eloneva S., Teir S., Revitzer H., Salminen J., Said A., Fogelholm C. -J., Zevenhoven, R., Reduction of $\mathrm{CO}_{2}$ Emissions from Steel Plants by Using Steelmaking Slags for Production of Marketable Calcium Carbonate, Steel Res. Int., 2009, 80(6), 415-421

[45] Eloneva S., Mannisto P., Said A., Fogelholm C. -J., Zevenhoven R., Ammonium salt-based steelmaking slag carbonation: Precipitation of $\mathrm{CaCO}_{3}$ and ammonia losses assessment, Greenhouse Gas Sci. Technol., 2011, 1(4), 305-311

[46] Huijgen W. J. J., Comans R. N. J., Carbonation of Steel Slag for $\mathrm{CO}_{2}$ Sequestration: Leaching of Products and Reaction Mechanisms, Environ Sci Technol., 2006, 40, 2790-2796

[47] Topkaya Y., Sevinç N., Günaydın A., Slag treatment at Kardemir integrated iron and steel works, Int. J. Miner. Process., 2004, 74, 31-39

[48] Dippenaar R., Industrial uses of slag (the use and re-use of iron and steelmaking slags), Ironmak Steelmak., 2005, 32, 35-46

[49] Wang G., Wang Y., Gao Z., Use of steel slag as a granular material: volume expansion prediction and usability criteria, J. Hazard Mater., 2010, 184, 555560

[50] Emery J. J., Slag utilization in pavement construction, Extending Aggr. Resour., Astm. Spec. Tech. Publ., 1982, 774, 95-118

[51] Mikhail S. A., Turcotte A. M., Thermal behaviour of basic oxygen furnace waste slag, Thermochim. Acta, 1995, 263, 87-94

[52] Waligora J., Bulteel D., Degrugilliers P., Damidot D. et al., Chemical and mineralogical characterizations of LD converter steel slags: A multi-analytical techniques approach, Mater. Charact., 2010, 61, 39-48

[53] Huijgen W. J. J., Witkamp G. -J., Comans R. N. J., Mineral $\mathrm{CO}_{2}$ Sequestration by Steel Slag
Carbonation, Environ. Sci. Technol., 2005, 39, 9676-9682

[54] Chang E. -E., Pan S. -Y., Chen Y. -H., Tan C. S. et al., Accelerated carbonation of steelmaking slags in a high-gravity rotating packed bed, J. Hazard Mater., 2012, 227-228, 97-106

[55] van Zomeren A., van der Laan S. R., Kobesen H. B. A., Huijgen W. J. J., et al., Changes in mineralogical and leaching properties of converter steel slag resulting from accelerated carbonation at low $\mathrm{CO}_{2}$ pressure, Waste Manage., 2011, 31, 2236-2244

[56] Isoo T., Takahashi T., Fukuhara M., Using carbonated steelmaking slag blocks to help reduce $\mathrm{CO}_{2}$, Am. Ceram. Soc. Bull., 2001, 80, 73-75

[57] Yu J., Wang K., Study on characteristics of steel slag for $\mathrm{CO}_{2}$ capture, Energy Fuels, 2011, 25, 5483-5492

[58] Saikia N., Cornelis G., Mertens G., Elsen J. et al., Assessment of Pb-slag, MSWI bottom ash and boiler and fly ash for using as a fine aggregate in cement mortar, J. Hazard Mater., 2008, 154, 766-777

[59] Baciocchi, R., Costa, G., Di Bartolomeo, E., Polettini, A. et al., Wet versus slurry carbonation of EAF steel slag, Greenhouse Gas Sci. Technol., 2011, 1, 312319

[60] Huaiwei H., Xin H., An overview for the utilization of wastes from stainless steel industries, Resour. Conserv. Recycl., 2011, 55, 745-754

[61] Durinck D., Engström F., Arnout S., Heulens J. et al., Hot stage processing of metallurgical slags, Resour Conserv Recycl. 2008, 52, 1121-1131

[62] Domínguez M. I., Romero-Sarria F., Centeno M. A., Odriozola J. A., Physicochemical Characterization and Use of Wastes from Stainless Steel Mill, Environ Prog Sustainable Energy 2010, 29, 471480

[63] Mayes W. M., Younger P. L., Aumônier J., Hydrogeochemistry of Alkaline Steel Slag Leachates in the UK, Water Air Soil Pollut., 2008, 195, 35-50

[64] Pontikes Y., Jones P. T., Geysen D., Blanpain B., Options to prevent dicalcium silicate-driven disintegration of stainless steel slags, Arch. Metall. Mater. 2010, 55, 1167-1172

[65] Vandevelde E., Mineral carbonation of stainless steel slag, Master's Thesis, KU Leuven, Leuven, Belgium, 2010

[66] Santos R. M., Ling D., Guo M., Blanpain B., Van Gerven T., Valorisation of thermal residues by intensified mineral carbonation, In: Proceedings of the $50^{\text {th }}$ Conference of Metallurgists and the $6^{\text {th }}$ International Symposium on Waste Recycling in 
Mineral and Metallurgical Industries (2-5 October 2011 Montreal Canada), 2011, art.nr. 47189

[67] Van Bouwel J., Intensified aqueous mineral carbonation of alkaline industrial residues for $\mathrm{CO}_{2}$ storage and waste remediation: effect of process parameters on carbonation conversion, leaching behavior and mineralogy, Master's Thesis, KU Leuven, Leuven, Belgium, 2012

[68] Santos R. M., Van Bouwel J., Vandevelde E., Mertens G. et al., Accelerated mineral carbonation of stainless steel slags for $\mathrm{CO}_{2}$ storage and waste valorization: effect of process parameters on geochemical properties, Int. J. Greenhouse Gas Control 2013c, 17, 32-45

[69] Arickx S., Van Gerven T., Vandecasteele C., Accelerated carbonation for treatment of MSWI bottom ash, J. Hazard Mater., 2006, B137, 235-243

[70] Van Gerven T., Van Keer E., Arickx S., Jaspers M. et al., Carbonation of MSWI-bottom ash to decrease heavy metal leaching, in view of recycling, Waste Manage., 2005, 25, 291-300

[71] Costa G., Baciocchi R., Polettini A., Pomi R. et al., Current status and perspectives of accelerated carbonation processes on municipal waste combustion residues, Environ. Monit. Assess., 2007, 135, 55-75

[72] Rendek E., Ducom G., Germain P., Influence of organic matter on municipal solid waste incinerator bottom ash carbonation, Chemosphere, 2006a, 64, 1212-1218

[73] Baciocchi R., Costa G., Lategano E., Marini C. et al., Accelerated carbonation of different size fractions of bottom ash from RDF incineration, Waste Manage., 2010b, 30, 1310-1317

[74] Rendek E., Ducom G., Germain P., Carbon dioxide sequestration in municipal solid waste incinerator (MSWI) bottom ash, J. Hazard Mater., 2006b, B128, 73-79

[75] Um N., Nam S. Y., Ahn J. W., Effect of accelerated carbonation on the leaching behavior of $\mathrm{Cr}$ in municipal solid waste incinerator bottom ash and the carbonation kinetics, In: Proceedings of the Fourth International Conference on Accelerated Carbonation for Environmental and Materials Engineering (April 9-12, 2013 Leuven Belgium), 2013, 529-533

[76] Santos R. M., Mertens G., Salman M., Cizer Ö. et al., Comparative study of ageing, heat treatment and accelerated carbonation for stabilization of municipal solid waste incineration bottom ash in view of reducing regulated heavy metal/metalloid leaching, J. Environ. Manage., 2013d, 128, 807-821
[77] Larachi F., Gravel J. -P., Grandjean B. P. A., Beaudoin G., Role of steam, hydrogen and pretreatment in chrysotile gas-solid carbonation: Opportunities for pre-combustion $\mathrm{CO}_{2}$ capture, Int. J. Greenhouse Gas Control, 2012, 6, 69-76

[78] Assima G. P., Larachi F., Molson J., Beaudoin G., Assessment of the impact of seasonal temperature variations on the dynamics of $\mathrm{CO}_{2}$ mineral sequestration by nickel mining residues, In: Proceedings of the Fourth International Conference on Accelerated Carbonation for Environmental and Materials Engineering (April 9-12, 2013 Leuven Belgium), 2013, 245-254

[79] Gerdemann S. J., O'Connor W. K., Dahlin D. C., Penner L. R. et al., Ex Situ Aqueous Mineral Carbonation, Environ Sci Technol., 2007, 41, 25872593

[80] Gualtieri A. F., Cavenati C., Zanatto I., Meloni M. et al., The transformation sequence of cement-asbestos slates up to $1200^{\circ} \mathrm{C}$ and safe recycling of the reaction product in stoneware tile mixtures, J. Hazard Mater., 2008, 152, 563-570

[81] Gualtieri A. F., Boccaletti M., Recycling of the product of thermal inertization of cement-asbestos for the production of concrete, Constr. Build Mater., 2011, 25, 3561-3569

[82] Larachi F., Daldoul I., Beaudoin G., Fixation of $\mathrm{CO}_{2}$ by chrysotile in low-pressure dry and moist carbonation: Ex-situ and in-situ characterizations, Geochim. Cosmochim. Acta, 2010, 74, 3051-3075

[83] Ryu K. W., Chae S. C., Jang Y. N., Carbonation of chrysotile under subcritical conditions, Mater Trans., 2011a, 52(10), 1983-1988

[84] Ryu K. W., Lee M. G., Jang Y. N., Mechanism of tremolite carbonation, Appl. Geochem., 2011b, 26, 1215-1221

[85] Gadikota G., Natali C., Boschi C., Park A. H. A., Carbonation of Asbestos for Permanent Storage of Anthropogenic $\mathrm{CO}_{2}$, In: Proceedings of the Fourth International Conference on Accelerated Carbonation for Environmental and Materials Engineering (April 9-12, 2013 Leuven Belgium), 2013, 255-264

[86] Meyer N. A., Vogeli J., Becker M., Broadhurst J. L, et al., Mineral carbonation of PGM mine tailings for $\mathrm{CO}_{2}$ storage in South Africa: A case study from Lonmin, In: Proceedings of the Fourth International Conference on Accelerated Carbonation for Environmental and Materials Engineering (April 9-12, 2013 Leuven Belgium), 2013, 503-507

[87] Gräfe M. Power G., Klauber C., Review of bauxite 
residue alkalinity and associated chemistry, CSIRO Document DMR-3610, May 2009

[88] Si C., Ma Y., Lin C., Red mud as a carbon sink: Variability, affecting factors and environmental significance, J. Hazard Mater., 2013, 244-245, 54-59

[89] Santini T. C., Hinz C., Rate A. W., Carter C. M. et al., In situ neutralization of uncarbonated bauxite residue mud by cross layer leaching with carbonated bauxite residue mud, J. Hazard Mater, 2011, 194, 119-127

[90] Bonenfant D., Kharoune L., Sauvé S., Hausler R. et al., $\mathrm{CO}_{2}$ Sequestration by Aqueous Red Mud Carbonation at Ambient Pressure and Temperature, Ind. Eng. Chem. Res., 2008, 47, 7617-7622

[91] Yadav V. S., Prasad M., Khan J., Amritphale S. S. et al., Sequestration of carbon dioxide $\left(\mathrm{CO}_{2}\right)$ using red mud, J. Hazard Mater., 2010, 176, 1044-1050

[92] Sahu R. C., Patel R. K., Ray B. C., Neutralization of red mud using $\mathrm{CO}_{2}$ sequestration cycle, J. Hazard Mater., 2010, 179, 28-34

[93] Khaitan S., Dzombak D. A., Lowry G. V., Mechanisms of Neutralization of Bauxite Residue by Carbon Dioxide, J. Environ. Eng., 2009, 135, 433-438

[94] Dilmore R., Lu P., Allen D., Soong Y. et al., Sequestration of $\mathrm{CO}_{2}$ in Mixtures of Bauxite Residue and Saline Wastewater, Energy Fuels, 2008, 22, 343-353

[95] Soong Y., Dilmore R. M., Hedges S. W., Howard B. H. et al., Utilization of Multiple Waste Streams for Acid Gas Sequestration and MultiPollutant Control, Chem Eng Technol., 2012, 35(3), 473-481

[96] Uibu M., Uus M., Kuusik R., $\mathrm{CO}_{2}$ mineral sequestration in oil-shale wastes from Estonian power production, J. Environ. Manage., 2009, 90, 1253-1260

[97] Uibu M., Kuusik R., Mineral trapping of $\mathrm{CO}_{2}$ via oil shale ash aqueous carbonation: controlling mechanism of process rate and development of continuous-flow reactor system, Oil Shale, 2009, 26(1), 40-58

[98] Uibu M., Velts O., Kuusik R., Developments in $\mathrm{CO}_{2}$ mineral carbonation of oil shale ash, J. Hazard Mater., 2010, 174, 209-214
[99] Monkman S., Shao Y., Shi C., Carbonated Ladle Slag Fines for Carbon Uptake and Sand Substitute, J. Mater Civ Eng., 2009, 21(11), 657-665

[100] Salman M., Cizer Ö., Pontikes Y., Vandewalle L. et al., Carbonation potential of continuous casting stainless steel slag, In: Proceedings of the Fourth International Conference on Accelerated Carbonation for Environmental and Materials Engineering (April 9-12, 2013 Leuven Belgium), 2013, 317-327

[101] Van Mechelen D., Quaghebeur M., Evlard J., Nielsen P. et al., Development of a pilot plant for mineral carbonation of waste materials, In: Proceedings of the Fourth International Conference on Accelerated Carbonation for Environmental and Materials Engineering (April 9-12, 2013 Leuven Belgium), 2013, 509-511

[102] Baciocchi R., Costa G., Morone M., Polettini A. et al., Valorization of steel slag by a combined carbonation and granulation treatment, In: Proceedings of the Fourth International Conference on Accelerated Carbonation for Environmental and Materials Engineering (April 9-12, 2013 Leuven Belgium), 2013, 329-338

[103] Gunning P., Hills C. D., Carey P. J., Commercial Application of Accelerated Carbonation: Looking Back at the First Year, In: Proceedings of the Fourth International Conference on Accelerated Carbonation for Environmental and Materials Engineering (April 9-12, 2013 Leuven Belgium), 2013, 185-192

[104] Hills C. D., Carey P. J., Production of secondary aggregates, US Patent Application, 2009/0104349 A1, 2009

[105] Gunning P. J., Hills C. D., Carey P. J., Production of lightweight aggregate from industrial waste and carbon dioxide, Waste Manage., 2009, 29, 27222728

[106] Maroto-Valer M. M., Mineral carbonation: Developing decentralised CCS technologies, Keynote at Fourth International Conference on Accelerated Carbonation for Environmental and Materials Engineering (April 9-12, 2013 Leuven Belgium), 2013 